\title{
Nonlinearities and asymmetric adjustment to PPP in an exchange rate model with inflation expectations
}

Nonlinearities and asymmetric adjustment

Christina Anderl

London South Bank University, London, UK, and

Guglielmo Maria Caporale

Brunel University London, Uxbridge, UK
Received 24 February 2021 Revised 17 May 2021 17 June 2021

Accepted 23 June 2021

\begin{abstract}
Purpose - This paper aims to explain real exchange rate fluctuations by means of a model including both standard fundamentals and two alternative measures of inflation expectations for five inflation targeting countries (the UK, Canada, Australia, New Zealand and Sweden) over the period January 1993-July 2019.

Design/methodology/approach - Both a benchmark linear autoregressive distributed lag (ARDL) model and a nonlinear autoregressive distributed lag (NARDL) specification are considered.

Findings - The results suggest that the nonlinear framework is more appropriate to capture the behaviour of real exchange rates given the presence of asymmetries both in the long and short run. In particular, the speed of adjustment towards the purchasing power parity (PPP) implied long-run equilibrium is three times faster in a nonlinear framework, which provides much stronger evidence in support of PPP. Moreover, inflation expectations play an important role, with survey-based ones having a more sizable effect than marketbased ones.

Originality/value - The focus on linearities and the estimation of a NARDL model, which is shown to outperform the linear ARDL model both within sample and out of sample, is an important contribution to the existing literature which has rarely applied this type of framework; the choice of an appropriate econometric method also makes the policy implications of the analysis more reliable; in particular, monetary authorities should aim to achieve a high degree of credibility to manage them and thus currency fluctuations effectively; the inflation targeting framework might be especially appropriate for this purpose.
\end{abstract}

Keywords Nonlinearities, Asymmetric adjustment, PPP, Real exchange rate, Inflation expectations

Paper type Research paper

\section{Introduction}

The well-known PPP (purchasing power parity) puzzle (Rogoff, 1996) consists in the fact that real exchange rates appear to be more volatile and to exhibit more persistence than implied by most exchange rate determination models. This has generated an extensive literature aiming to understand the reasons for the empirical failure of PPP (see Taylor, 2006 for a thorough review). Various empirical methods have been used for this purpose, including unit root and cointegration tests and have produced mixed results (see, e.g. Chortareas and Kapetanios, 2009; Norman, 2010; Taylor et al., 2001). An important issue in this context is the possible role of the monetary policy framework adopted by central banks (Lavesson, 2011). It is

\section{JEL Classification - C32, F31, G15}

(C) Christina Anderl and Guglielmo Maria Caporale. Published by Emerald Publishing Limited. This article is published under the Creative Commons Attribution (CC BY 4.0) licence. Anyone may reproduce, distribute, translate and create derivative works of this article (for both commercial and noncommercial purposes), subject to full attribution to the original publication and authors. The full terms of this licence may be seen at http://creativecommons.org/licences/by/4.0/legalcode

The authors are grateful to three anonymous referees for their useful comments and suggestions. 
JES

49,6

938

noteworthy that only a few papers have carried out this type of analysis in the case of inflation targeting countries, which appear to be characterised by faster mean reversion (Ding and Kim, 2012) and lower volatility (Kim, 2014) of the real exchange rate.

The present paper aims to shed new light on these issues by estimating a model of the real exchange rate including economic fundamentals as well as inflation expectations in the case of five countries with an inflation targeting regime, namely the UK, Canada, Australia, New Zealand and Sweden, over the period from January 1993 to July 2019; in such countries the credibility of the central bank can directly affect inflation expectations and through them deviations of the real exchange rate from the PPP-implied long-run equilibrium. The five countries under examination have been the first to adopt inflation targeting and have generally been successful in stabilising inflation despite experiencing a stronger pass-through of exchange rate changes to import prices than non-targeters (Dodge, 2002; Allsopp et al., 2006); moreover, they have achieved lower exchange rate volatility. Thus, they represent an interesting case study for evaluating the empirical validity of PPP. Various recent papers have estimated autoregressive distributed lag (ARDL) models to investigate PPP (see, e.g. Ariff and Zarei, 2015), therefore we start the analysis using this type of econometric framework but, given the possible importance of nonlinearities and asymmetric adjustment to the long-run equilibrium in the case of real exchange rates (see Taylor et al., 2001), we also estimate a nonlinear autoregressive distributed lag (NARDL) model including fundamentals and two alternative measures of inflation expectations. The role of inflation expectations is particularly important in the context of inflation targeting, and thus our empirical framework incorporates them.

The layout of the paper is as follows. Section 2 briefly reviews the relevant literature; Section 3 outlines the econometric models used for the analysis; Section 4 discusses the data and the empirical results; Section 5 offers some concluding remarks.

\section{Literature review}

The empirical literature on PPP is extensive. Early studies carrying out augmented DickeyFuller (ADF) unit root tests on the real exchange rate mostly rejected PPP (Froot and Rogoff, 1995; Lothian and Taylor, 1996), whilst stronger evidence supporting it was found by papers using the more powerful Dickey-Fuller generalised least squares (DF-GLS) test (see, e.g. Cheung and Lai, 1994). However, it is now well known that all such tests have low power in detecting mean reversion (Taylor, 2001). Therefore subsequent studies have used panel methods instead. Frankel and Rose (1996) found that deviations from PPP have half-lives of approximately four years in a panel of 150 countries, and similar results were obtained by Rogoff (1996). Coakley and Fuertes (1997) used panel unit toot tests to assess mean reversion of the real exchange rate in the G10 countries and found half-lives of less than three years, whilst Wu (1996) and Papell (1997) obtained estimates of 2.0 and 2.5 years, respectively. Murray and Papell (2005) applied a median-unbiased panel method that produced estimates of approximately 4 years for half-lives. Using heterogeneous unit root tests in a panel with 25 OECD countries Chortareas and Kapetanios (2009) found strong evidence of mean reversion. Ca'Zorzi et al. (2016) concluded that a half-life PPP model is able to forecast real exchange rates better than the random walk model at both short- and long-term horizons.

Some other studies allow for possible nonlinearities in the adjustment process to the longrun equilibrium implied by PPP. Taylor et al. (2001) performed multivariate unit root tests using the empirical critical values obtained by means of Monte Carlo simulations to analyse a number of real exchange rates during the Bretton-Woods period; they found faster mean reversion when these are further away from their equilibrium value. Baum et al. (2001) estimated an exponential smooth transition autoregression (STAR) model based on the Johansen cointegration method and found evidence of nonlinear mean reversion with an adjustment speed which is dependent on the size of the deviation from equilibrium. Sollis et al. 
(2002) used a similar nonlinear STAR model to test for asymmetries in the mean reversion of the real exchange rate and reported stronger rejections of the unit root null hypothesis than when carrying out standard unit root tests. Chortareas et al. (2002) used the same STAR framework to assess whether the G7 real exchange rates follow a nonlinear stationary process. Specifically, they implemented a de-trending method suggested by Schmidt and Phillips (1992) to derive an alternative test statistic which is more powerful against linear trend-stationary processes and found evidence of nonlinear mean reversion of most real exchange rates even in cases where standard unit root tests were unable to detect linear mean reversion. These results were confirmed by Bahmani-Oskooee et al. (2008), who used the nonlinear unit root test suggested by Kapetanios et al. (2003) to assess the validity of PPP in 23 countries in a STAR framework; they found nonlinear mean reversion and more evidence for PPP than when using the standard ADF test.

Norman (2010) estimated a STAR model to determine the empirical distribution of half-lives in response to frequent shocks. His findings provide evidence of nonlinear mean reversion with half-lives of less than the typical $3-5$ years reported in previous studies. He concluded that halflives of less than 5 years occur $100 \%$ of the time and half-lives of less than 3 years $30 \%$ of the time. This confirms that nonlinear mean reversion is a key feature of the real exchange rate and a potential solution to the PPP puzzle. Christopoulos and León-Ledesma (2010) developed a test for unit roots which allows for multiple endogenous breaks and for adjustments following a nonlinear exponential STAR process and applied it to 15 bilateral real exchange rates against the US dollar during the Bretton-Woods period; they found nonlinear mean reversion of the real exchange rate to a smooth-breaking mean in almost all cases. Feenstra and Kendall (1997) reported that the pass-through behaviour of the exchange rate is able to explain at least onethird of the deviation from PPP, while interest differentials, which are mostly stationary, are unable to account for the mostly nonstationary deviations from PPP.

As can be gathered from the discussion above, various studies concerned with PPP focus on the estimation of half-lives, which measure the time (in years) it takes for a deviation of the exchange rate from its equilibrium to be reduced by $50 \%$ and provide interesting insights into the degree of mean reversion of the real exchange rate (King, 2012).

On the whole, the extensive evidence of nonlinearities and asymmetries in real exchange rate behaviour reviewed above motivates our estimation of a NARDL model in addition to the standard ARDL specification as discussed in the next section.

\section{Empirical framework}

\subsection{The ARDL model}

To investigate the issues of interest we start by following a standard ARDL approach (see Pesaran and Shin, 1998 for more details). In its general form the linear benchmark model can be expressed as follows:

$$
y_{t}=\sum_{i=1}^{p} \varphi_{i} \Delta x_{t-i}+\sum_{j=1}^{q} \theta_{j} x_{t-j}+\varepsilon_{t}
$$

where $x_{t-j}$ are the lagged explanatory variables and $\Delta$ stands for the difference operator. We apply this framework to estimate the following model of the real exchange rate:

$$
q_{t}=\theta_{t} \tilde{m}_{t}-\varphi_{t} \tilde{y}_{t}+\lambda_{t} \tilde{i}_{t}+\omega_{t} \tilde{x}_{t}+\varepsilon_{t}
$$

where $q_{t}$ is the real exchange rate, $\tilde{m}_{t}=m_{t}-m_{t}^{*}$ is the difference between domestic and foreign money supply (in nominal terms), $\tilde{y}_{t}=y_{t}-y_{t}^{*}$ is the difference between domestic and foreign output (in real terms), $\tilde{i}_{t}=i_{t}-i_{t}^{*}$ is the nominal interest rate differential and finally 
JES

49,6

940

$\tilde{x}_{t}=x_{t}-x_{t}^{*}$ is the inflation expectation differential. This variable is included following Kamada and Nakajima (2014), who suggest that the real exchange rate should be defined as $q_{t}=\frac{x_{t}^{*}}{x_{t}} \times s_{t}$, namely as the difference between inflation expectations multiplied by the nominal exchange rate, which can be informative about the role of central bank credibility in the context of PPP. The chosen setup allows for the possible effects of both real and nominal shocks, since the latter can also influence the real exchange rate in the presence of sluggish price adjustment (Stockman, 1987; Clarida and Gali, 1994).

The empirical specification of the model is the following:

$$
\begin{gathered}
\Delta q_{t}=\alpha+\sum_{i}^{p} \gamma_{i} \Delta q_{t-i}+\varphi_{1} \Delta \tilde{m}_{t-1}+\varphi_{2} \Delta \tilde{i}_{t-1}+\varphi_{3} \Delta \tilde{y}_{t-1}+\varphi_{4} \Delta \tilde{x}_{t-1}+\rho e c m_{t-1}+ \\
+\theta_{1} \tilde{m}_{t-1}+\theta_{2} \tilde{i}_{t-1}+\theta_{3} \tilde{y}_{t-1}+\theta_{4} \tilde{x}_{t-1}+\varepsilon_{t}
\end{gathered}
$$

where the variables are defined as before.

The individual series have to be tested for their order of integration since variables whose order is higher than I(1) cannot be included in the model. For this purpose, we carry out the DF-GLS test. After estimating the linear model, we assess its adequacy by carrying out a number of diagnostic tests, namely the Breusch-Pagan test for heteroscedasticity, the Breusch-Godfrey Lagrange multiplier (LM) test for serial correlation and a Wald test of the null hypothesis that the regressors are weakly exogenous.

\subsection{The NARDL (nonlinear ARDL) model}

Given the evidence from the existing literature on possible nonlinearities in real exchange rate behaviour we then consider a NARDL specification which allows for asymmetric effects of the regression parameters. For a start, we use the standard BDS (Broock, Scheinkman, Dechert and LeBaron) test for nonlinear dependence for both the individual series and the ARDL model residuals (Broock et al., 1996). A rejection of the null of independently and identically distributed data against the alternative of nonlinear dependence suggests that the NARDL model is more suitable than the ARDL one for the series under examination (Skare et al., 2019). We also test for the possible presence of structural breaks by employing the CUSUM (cumulative sum) test for parameter stability and carry out other diagnostic tests and parameter symmetry tests after the estimation has been performed.

The NARDL model allows the long-run cointegrating relation between the variables as well as the short-run dynamics to be characterised by asymmetries and thus to distinguish between the impact of positive and negative changes in variables such as inflation expectations on PPP deviations and the real exchange rate adjustment to equilibrium (Arize et al.,2017). It was developed by Shin et al. (2014) and is a fairly novel addition to the class of nonlinear cointegration models. Within this framework, the regressors can be decomposed by using the partial sum of positive and negative changes, which allows to test the relationship for short-and/or long-run asymmetries or for a combination of the two (the so-called dynamic multiplier) which might arise.

The NARDL $(p, q)$ model can then be represented as follows:

$$
y_{t}=\sum_{i=1}^{p} \varphi_{j} \Delta x_{t-i}+\sum_{j=0}^{q}\left(\theta_{j}^{+^{\prime}} x_{t-j}^{+}+\theta_{j}^{-\prime} x_{t-j}^{-}\right)+\varepsilon_{t}
$$

where $x_{t}$ is a $k \times 1$ vector of multiple regressors, which are defined such that $x_{t}=x_{0}+x_{t}^{+}+x_{t}^{-} \cdot \varphi_{j}$ is the autoregressive parameter and $\theta_{j}^{+}$and $\theta_{j}^{-}$are the positive and negative distributed lag parameters capturing the asymmetries. The corresponding error correction specification takes the following general form: 


$$
\Delta y_{t}=\mu+\rho e c m_{t-1}+\gamma \Delta y_{t-1}+\sum_{j=1}^{q}\left(\varphi_{j}^{+^{\prime}} \Delta x_{t-j}^{+}+\varphi_{j}^{-{ }^{\prime}} \Delta x_{t-j}^{-}\right)+\sum_{j=1}^{q}\left(\theta_{j}^{+^{\prime}} x_{t-j}^{+}+\theta_{j}^{-^{\prime}} x_{t-j}^{-}\right)+\varepsilon_{t}
$$

and the specific model we estimate is the following:

$$
\begin{aligned}
& \Delta q_{t}=\alpha+\sum_{i}^{p} \gamma_{i} \Delta q_{t-i}+\varphi_{1}^{+{ }^{\prime}} \Delta \tilde{m}_{t-1}^{+}+\varphi_{1}^{-^{\prime}} \Delta \tilde{m}_{t-1}^{-}+\varphi_{2}^{+^{\prime}} \Delta \tilde{x}_{t-1}^{+}+\varphi_{2}^{-^{\prime}} \Delta \tilde{x}_{t-1}^{-}+ \\
& +\varphi_{3}^{+^{\prime}} \Delta \tilde{i}_{t-1}^{+}+\varphi_{3}^{-^{\prime}} \Delta \tilde{i}_{t-1}^{-}+\varphi_{4}^{+^{\prime}} \Delta \tilde{y}_{t-1}^{+}+\varphi_{4}^{+^{\prime}} \Delta \tilde{y}_{t-1}^{-}+\rho e c m_{t-1}+\theta_{1}^{+^{\prime}} \tilde{m}_{t-1}^{+}+\theta_{1}^{-^{\prime}} \tilde{m}_{t-1}^{-}+ \\
& +\theta_{2}^{+{ }^{\prime}} \tilde{i}_{t-1}^{+}+\theta_{2}^{-\prime^{-}} i_{t-1}^{-}+\varepsilon_{t}
\end{aligned}
$$

Nonlinearities and asymmetric adjustment

where all variables are defined as before but are now entered as their partial sum decompositions. The difference between a traditional error correction model and an ARDL one is that in the latter the error correction term is replaced with the first lag of the dependent and cointegrating variables. This allows one to enter the same lagged variables in levels as in a standard error correction model, but without any restrictions on the coefficients. Therefore this model is also called a conditional or unrestricted error correction model. It is nonlinear in the variables but linear in the parameters on all short- and long-run variables (Shin et al., 2014). The null hypothesis that the positive and negative coefficients in the short- or long-run relationships are symmetric, i.e. $\left(\frac{-\theta^{+}}{\rho}\right)^{\prime}=\left(\frac{-\theta^{-}}{\rho}\right)^{\prime}$, can be tested by means of a Wald statistic (Ghodsi, 2017). The coefficient $\rho$ on the nonlinear error correction term, $e c m_{t-1}$, is defined as $\rho=q_{t}-\beta^{+1} x_{t}^{+}-\beta^{-1} x_{t}^{-}$where $x_{t}^{+}$and $x_{t}^{-}$are the positive and negative partial sum components of the variables which enter the long-run cointegration relation and $\beta^{+}=-\frac{\theta^{+}}{\rho}$ and $\beta^{-}=-\frac{\theta^{-}}{\rho}$ are the asymmetric long-run parameters. Since the model is linear in all parameters including the coefficients on the partial sum components of the regressors, it can be conveniently estimated by ordinary least squares (Pesaran and Shin, 1998).

The NARDL model is the nonlinear version of the ARDL one, which allows for the inclusion of both $I(1)$ and $I(0)$ variables but is unstable in the presence of variables with higher integration orders. It provides information about both the short-run dynamics and the long-run equilibrium in an error correction specification which also includes unrestricted lags of the regressors (Pesaran and Shin, 1998; Nkoro and Uko, 2016). An advantage of this model is that it corrects for weak endogeneity of nonstationary explanatory variables. Both the ARDL and NARDL approaches are only applicable if there is a single cointegrating vector, otherwise the Johansen and Juselius (1990) method needs to be adopted. The NARDL model can be estimated by OLS and inference allows differentiating between various types of asymmetries. This model has various advantages compared to the STAR-type models commonly used in this area of the literature. First, it allows to test for the existence of a longrun relationship regardless of whether the included variables are I(0) or I(1). Second, it accounts for nonlinearities by separating the positive and negative impact of changes in the included variables rather than by confining nonlinearities to an error correction term which depends on the value of a specified transition variable. Third, it allows for the impact of asymmetric shocks in both the short and long run, thus providing additional insights.

To test for the existence of a stable long-run relationship between the variables we use the dynamic Bounds testing procedure, which is valid regardless of whether the underlying regressors are $I(0)$ or $I(1)$. The Bounds test for the existence of an asymmetric long-run relationship is an $F$-test for the joint null $\rho=\theta^{+}=\theta^{-}=0$, where $\rho$ is the coefficient of the nonlinear error correction term in the NARDL model. The lower bound hypothesis is that all level regressors $x_{t}^{+}$and $x_{t}^{-}$are $I(0)$ and therefore there is no cointegrating relationship between the variables while the upper bound hypothesis is that that all level regressors are $I(1)$ and a 
JES

49,6

942

cointegrating relationship exists between the variables. The critical values for the test are provided by Pesaran et al. (2001); when the computed F-statistic exceeds the upper bound critical value then $H_{0}$ is rejected and there exists one cointegration relationship between the variables.

However, Pesaran and Shin (1998) argue that in small samples empirical critical values should be used for statistical inference. Therefore we perform a residual bootstrap to obtain empirical values and confidence intervals for the bounds test $F$-statistic. These are generated by estimating an appropriate NARDL model with optimal lag length by means of OLS while excluding the coefficient values on the independent weakly exogenous variables, which imposes restrictions of the null hypothesis of no cointegration for the $F$-test. This restricted model is estimated for the regressand while for the regressors an unrestricted NARDL model is estimated. The residuals of the models are saved, resampled with replacement and recentred, which generates the bootstrap residuals (Goh et al., 2017). Afterwards, the models are estimated again using the bootstrap sample and the bootstrap $t$ - and $F$-test statistics are generated. The above procedure is repeated 1,000 times to compute an entire bootstrap distribution from which bootstrap critical values can be obtained according to:

$$
\begin{aligned}
& c_{1-\alpha}^{*}=\min \left\{c: \sum_{b=1}^{B} I\left(T_{b}^{*}>c\right) \leq \alpha\right\} \\
& c_{\alpha}^{*}=\max \left\{c: \sum_{b=1}^{B} I\left(T_{b}^{*}<c\right) \leq \alpha\right\}
\end{aligned}
$$

where $T_{b}^{*}$ is the bootstrap test statistic and $\alpha$ is the nominal level of the test (McNown et al., 2018). The null hypothesis is rejected if the $F$-test statistic for the restricted model is greater than $c_{1-\alpha}^{*}$ or the $t$-test statistic for the unrestricted model is less than $c_{\alpha}^{*}$.

To assess model adequacy, we perform various diagnostic tests (Shin et al., 2014), specifically Wald tests for the symmetry of the short- and long-run parameters, LM tests for serial correlation, ARCH tests and CUSUM tests for parameter constancy. We also compare the in-sample and out-of-sample performance of the linear and the nonlinear ARDL models. In particular, we run rolling regressions with a 120-months window, using data over the period January 1993-December 2002 and use the remaining 187 observations data to produce out-ofsample forecasts. We then compute the mean squared prediction errors (MSPEs) of a 120months rolling window 1-month ahead forecast with real-time data obtained for both specifications, where a lower MSPE indicates a better forecasting performance (see Clark and West, 2007). The Clark and West test corrects for size distortions and adjusts for the negative bias in the difference between the two model MSPEs; therefore, it has been widely used in the recent exchange rate literature (see, for instance, Molodtsova and Papell, 2009; Ince, 2014). Finally, we estimate the half-lives for both the linear and nonlinear models.

\section{Data and empirical results}

\subsection{Data description}

We consider five inflation targeting countries, namely the UK, Canada, Australia, New Zealand and Sweden [1]. The series used for the analysis are monthly and span the period from January 1993 to July 2019. The nominal short-term interest rates are the monthly averages of the overnight lending rates charged by each central bank, more precisely for the UK the base rate published by the Bank of England, for Canada the Bank of Canada Overnight Repo Rate, for Australia the Reserve Bank of Australia Official Cash Rate, for New Zealand the Reserve Bank of New Zealand Official Cash Rate and for Sweden the Swedish market rate published by the Riksbank. The sources for the nominal broad money supply M3 series are the statistics database of each central bank and for real GDP (output approach) the 
OECD National Accounts database. The real effective CPI-based exchange rates series have been obtained from the BIS (Bank for International Settlements) Statistics Warehouse. Plots of the real exchange rate series are displayed in Figures 1-10. It can be seen that the British pound, the New Zealand dollar and the Swedish krona experienced an appreciation against
Nonlinearities and asymmetric adjustment

\section{3}

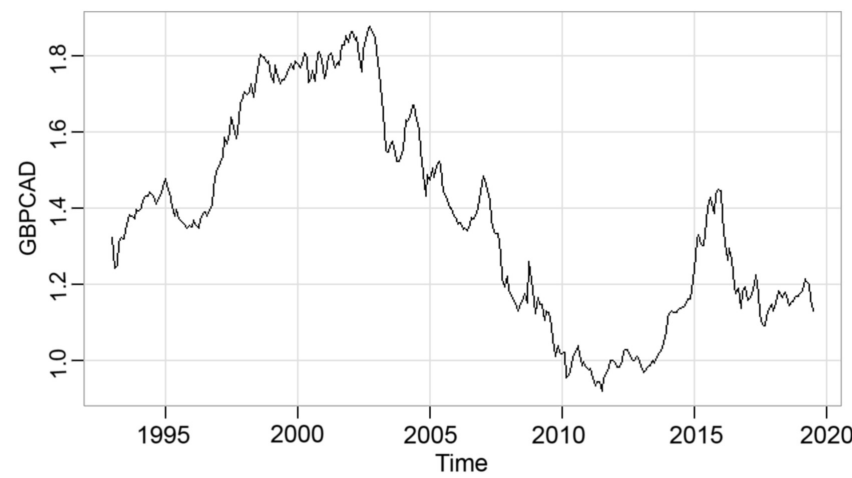

Figure 1.

GBPCAD real exchange rate series

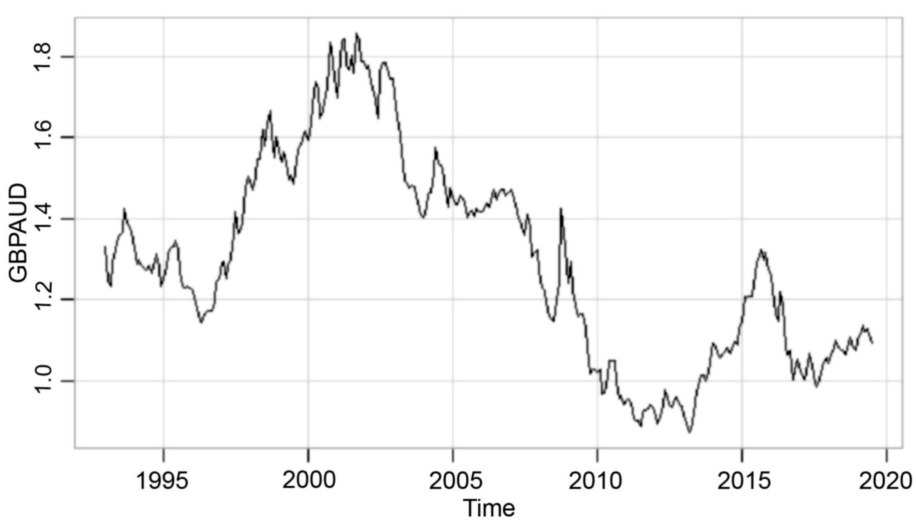

Figure 2. GBPAUD real exchange rate series

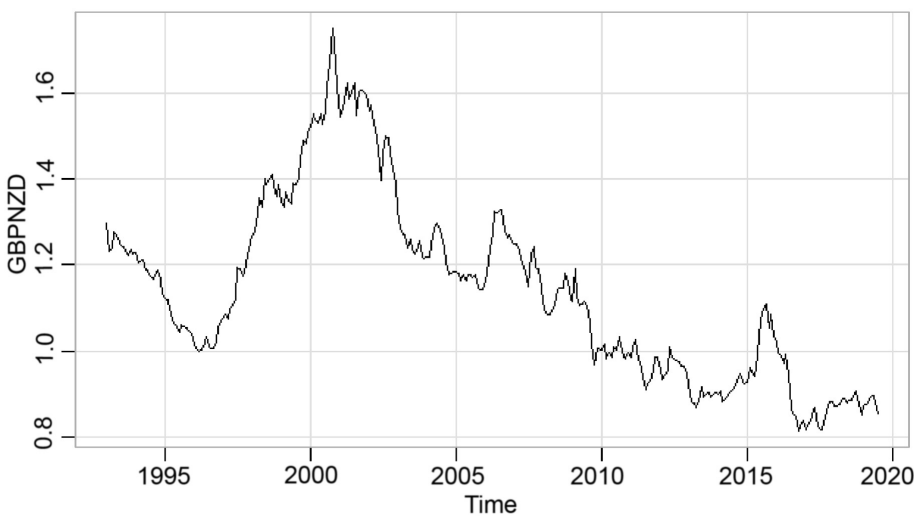

Figure 3. GBPNZD real exchange rate series 
JES

49,6

944

Figure 4

GBPSEK real

exchange rate series

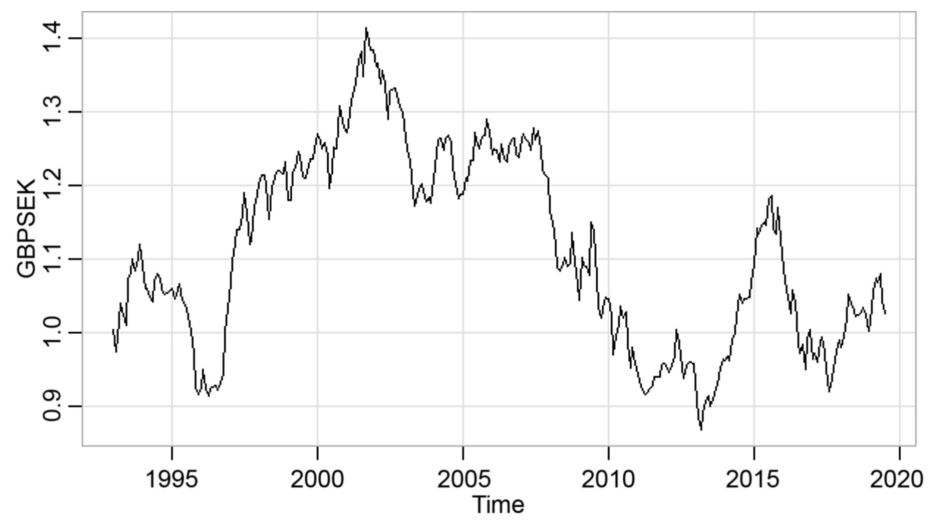

Figure 5.

CADAUD real

exchange rate series

Figure 6.

CADNZD real

exchange rate series
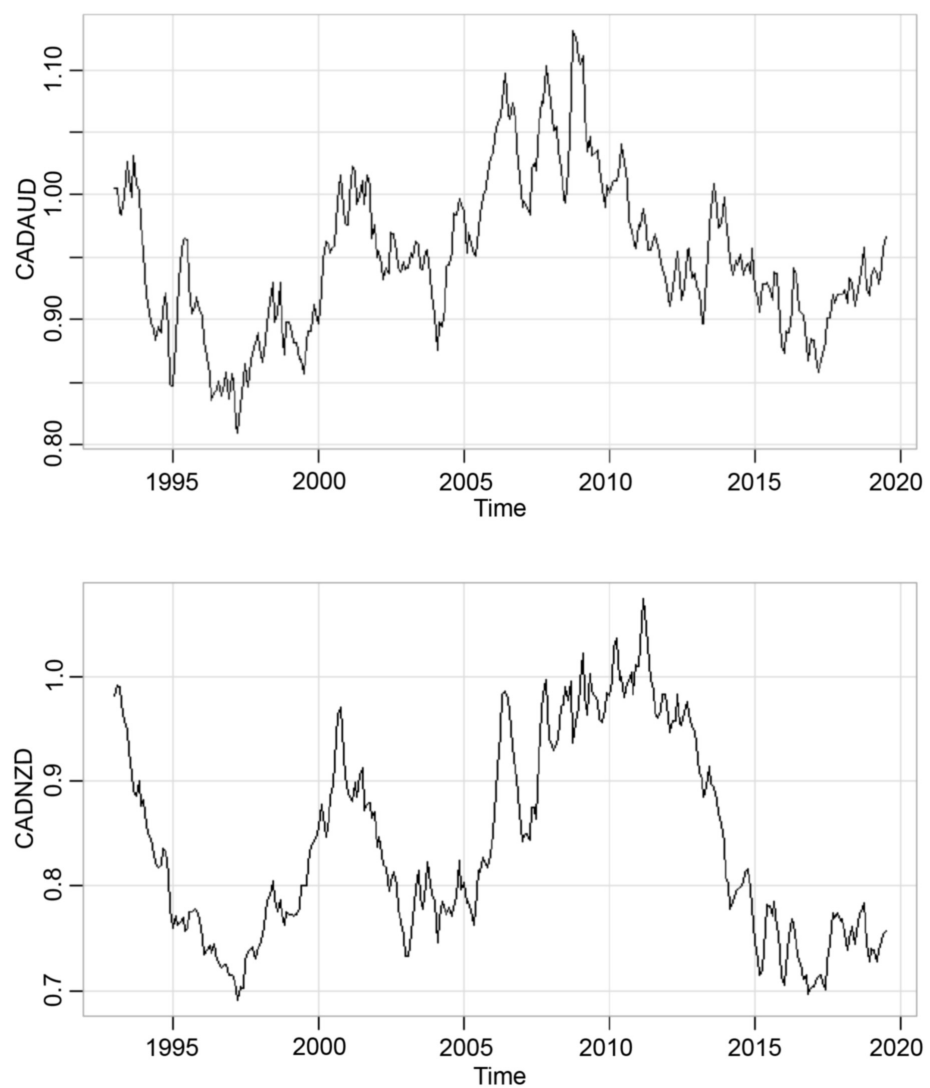

the other currencies at the time of the Global Financial Crisis, while the Canadian dollar and the Australian dollar depreciated. 


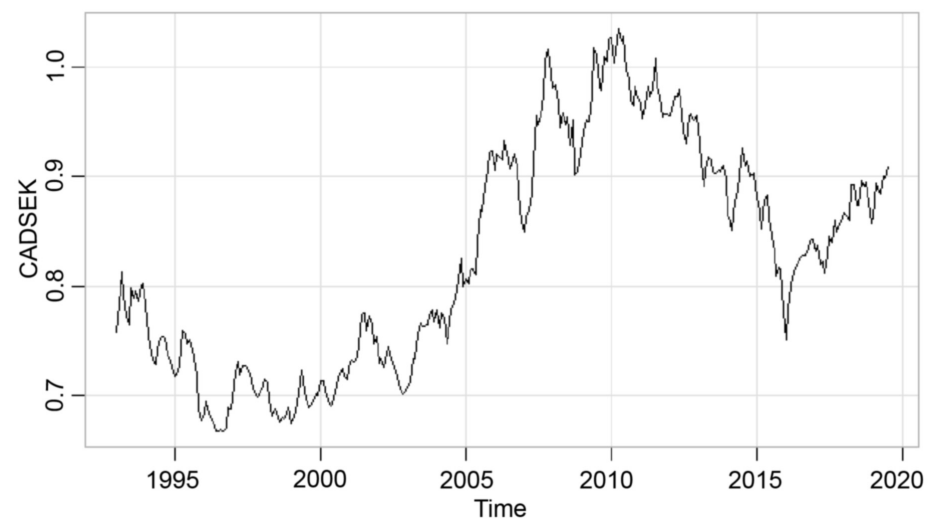

Nonlinearities and asymmetric adjustment

945

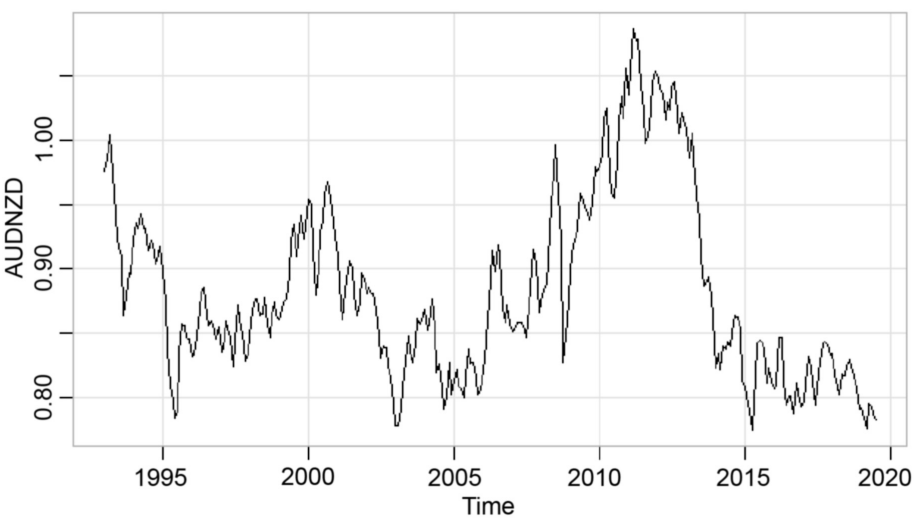

Figure 7. CADSEK real exchange rate series

Figure 8.

AUDNZD real exchange rate series

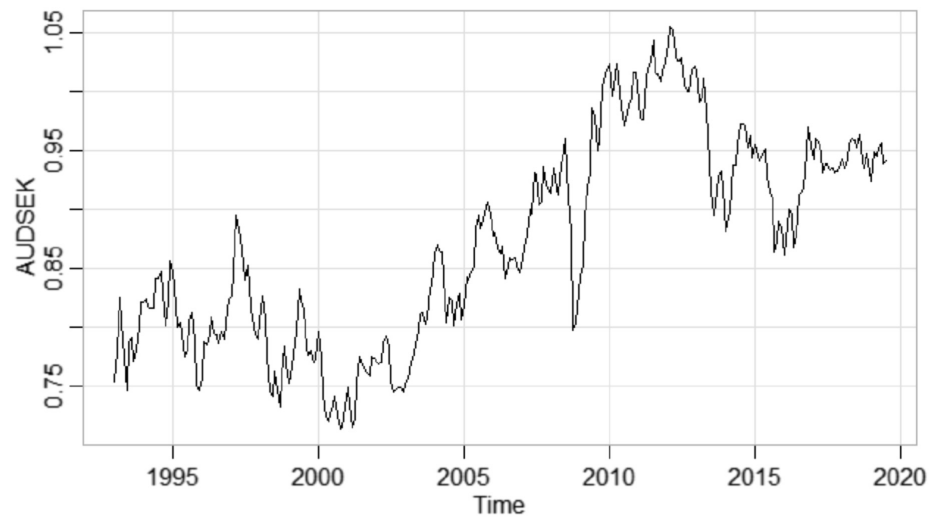

Figure 9.

AUDSEK real exchange rate series

As for inflation expectations, we use both market and survey data. Specifically, the yield curve data used to construct the market-based inflation expectations measure have been obtained from Bloomberg. For the UK and Canada the original sources are respectively the 
JES

49,6

\section{6}

Figure 10.

NZDSEK real exchange rate series

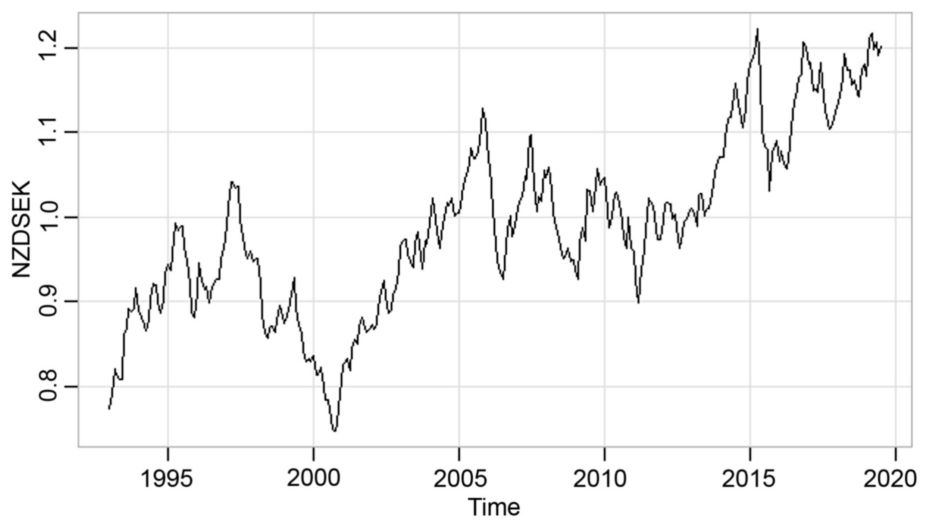

Inflation Attitudes Survey and the Canadian Survey of Consumer Expectations. For Australia, we use a survey measure of consumer expectations about increases in final prices for the 3-months ahead period published by the Reserve Bank of Australia. For New Zealand the series comes from the Reserve Bank's monetary conditions survey. Finally, for Sweden this series was obtained from the Riksbank's survey of inflation expectations.

As already mentioned, the market-based measure of inflation expectations is derived from the yield curve. Specifically, we take the difference between nominal and inflation-indexed 10years bond yields (the latter representing real forward interest rates), which is essentially the compensation demanded by investors to offset expected future inflation and any associated risks (Sack, 2000). A notable advantage of this measure is that market participants are directly compensated for the accuracy of their expectations, which makes it a less biased measure than survey measures. Low volatility of this measure suggests that the inflationtargeting framework has been successful in anchoring long-run inflation expectations. The second measure we use is based on quantitative rather than qualitative survey data. More precisely, we compute the monthly 12-months ahead mean inflation forecast. Unlike financial instrument-based measures, survey measures do not necessarily represent expectations on which agents are willing to act but have the advantage of being a more direct estimate of inflation expectations. Household and business survey measures are often criticised as predictors of inflation outcomes for being biased towards food and energy prices, but even if agents act on these biased expectations, they can still provide valuable information about spending and price setting behaviour (Sousa and Yetman, 2016). Overall, market-based indicators are found to perform poorly as predictors of inflation outcomes compared to survey measures (Bauer and McCarthy, 2015), which is why we would expect the latter measure to provide more insights into the behaviour of the real exchange rate.

As a first step, we test for the order of integration of all series using the DF-GLS test since, as already explained, variables of order higher than I(1) cannot be included in an ARDL model. The results in Table 1 imply that real exchange rates, money supply and interest rate differentials are I(1) while GDP and both inflation expectations measures are I(0); however, the ARDL model allows to test for the existence of a long-run relationship even if the variables exhibit different orders of integration and therefore we proceed to estimate it.

\subsection{Results for the ARDL model}

The results for the linear ARDL model are reported in Tables 2 and 3 below. It can be seen that the error correction coefficient is significant in most exchange rate models, which implies that in most cases there exists a long-run relationship between the real exchange rate and 


\begin{tabular}{|c|c|c|c|c|c|}
\hline \multirow{12}{*}{$\begin{array}{l}\text { UK-Canada } \\
\text { UK-Australia } \\
\text { UK-New Zealand } \\
\text { UK-Sweden } \\
\text { Canada-Australia } \\
\text { Canada-New Zealand } \\
\text { Canada-Sweden } \\
\text { Australia-New Zealand } \\
\text { Australia-Sweden } \\
\text { New Zealand-Sweden }\end{array}$} & \multirow{2}{*}{\multicolumn{2}{|c|}{$\begin{array}{c}\text { Level series Differenced series } \\
\text { Real exchange rate }\end{array}$}} & \multirow{2}{*}{\multicolumn{2}{|c|}{$\begin{array}{l}\text { Level series Differenced series } \\
\text { Interest rate differential }\end{array}$}} & \multirow{12}{*}{$\begin{array}{r}\text { Nonlinearities } \\
\text { and } \\
\text { asymmetric } \\
\text { adjustment }\end{array}$} \\
\hline & & & & & \\
\hline & -2.409633 & $-16.14660^{* * * *}$ & -2.906923 & \multirow{10}{*}{$\begin{array}{c}-12.95680 * * * \\
-7.266742^{* * * *} \\
-8.202538^{* * * *} \\
-8.718320^{* * * *} \\
-8.561225^{* * * *} \\
-9.431650 * * * \\
-8.998787^{* * * *} \\
-13.06459 * * * \\
-7.785444 \text { *** } \\
-7.981418^{* * *}\end{array}$} & \\
\hline & -1.806277 & $-14.15482^{* * * *}$ & -1.606476 & & \\
\hline & -2.244035 & $-15.27184^{* * * *}$ & -2.404156 & & \\
\hline & -2.335293 & $-14.01395^{* * *}$ & -3.412704 & & \\
\hline & -3.127759 & $-15.17735^{* * *}$ & -1.482159 & & \\
\hline & -2.457177 & $-15.36612^{* * *}$ & -1.956365 & & \\
\hline & -2.767811 & $-13.68189^{* * *}$ & -1.818217 & & \\
\hline & -3.083718 & $-15.01991 * * *$ & -2.614297 & & \\
\hline & -2.611152 & $-13.51788^{* * *}$ & -0.128862 & & \\
\hline & -2.405530 & $-12.82593 * * *$ & -0.279920 & & \\
\hline & \multicolumn{2}{|c|}{ Money supply differential } & \multicolumn{2}{|c|}{ Output differential } & \\
\hline UK-Canada & 0.726967 & $-11.16236^{* * *}$ & $-5.745060^{* * * *}$ & $-13.50751^{* * * *}$ & \\
\hline UK-Australia & -1.248922 & $-4.529805^{* * *}$ & $-5.538494^{* * * *}$ & $-13.37257^{* * * *}$ & \\
\hline UK-New Zealand & -0.178168 & $-4.623221 * * *$ & $-3.617988^{* *}$ & $-3.617988^{* *}$ & \\
\hline UK-Sweden & -1.576314 & $-6.571804 * * *$ & $-5.576428^{* * * *}$ & $-13.86241^{* * *}$ & \\
\hline Canada-Australia & 0.680567 & $-14.49548^{* * * *}$ & $-3.454509 * *$ & $-14.72166^{* * *}$ & \\
\hline Canada-New Zealand & -3.002544 & $-15.50797^{* * *}$ & $-4.728182^{* * *}$ & $-13.73744^{* * * *}$ & \\
\hline Canada-Sweden & -1.040547 & $-13.08886^{* * *}$ & $-5.921135^{* * *}$ & $-14.70774^{* * * *}$ & \\
\hline Australia-New Zealand & -0.218186 & $-4.131359 * * *$ & -7.719430 *** & $-14.73735^{* * *}$ & \\
\hline Australia-Sweden & -1.987129 & $-4.893552^{* * * *}$ & $-6.255319 * * *$ & $-14.92583^{* * *}$ & \\
\hline \multirow[t]{2}{*}{ New Zealand-Sweden } & -1.390497 & $-5.578336^{* * *}$ & $-6.600979 * * *$ & $-14.78302^{* * *}$ & \\
\hline & \multicolumn{2}{|c|}{$\begin{array}{c}\text { Market-based inflation expectations } \\
\text { differential }\end{array}$} & \multicolumn{2}{|c|}{$\begin{array}{l}\text { Survey-based inflation } \\
\text { expectations differential }\end{array}$} & \\
\hline UK-Canada & $-2.093259 * *$ & $-24.39729 * * *$ & $-3.007652^{* * * *}$ & $-18.85474^{* * * *}$ & \\
\hline UK-Australia & $-2.102593 * *$ & $-24.18133^{* * * *}$ & $-2.773300^{* * * *}$ & $-21.39735^{* * *}$ & \\
\hline UK-New Zealand & $-2.102116^{* *}$ & $-24.28768^{* * * *}$ & $-2.866010^{* * * *}$ & $-23.71241^{* * * *}$ & \\
\hline UK-Sweden & $-2.078134^{* *}$ & $-24.53556^{\text {*** }}$ & $-2.717170^{* * * *}$ & $-17.82799 * * *$ & \\
\hline Canada-Australia & $-3.759669^{* *}$ & $-11.45993^{* * * *}$ & $-6.102653^{* * *}$ & $-13.07812^{* * * *}$ & \\
\hline Canada-New Zealand & $-3.741017 * *$ & $-8.341847^{* * * *}$ & $-5.371546^{* * *}$ & $-24.24426^{* * *}$ & \\
\hline Canada-Sweden & $-3.547323^{* *}$ & $-18.69621^{* * * *}$ & $-5.801584^{* * * *}$ & $-14.46930^{* * * *}$ & \\
\hline Australia-New Zealand & $-4.135290^{* * * *}$ & -18.07779 *** & -5.967459 *** & -14.55439 *** & \\
\hline Australia-Sweden & $-2.705271 * * *$ & $-21.04204^{* * *}$ & $-6.845524^{* * * *}$ & $-14.19519^{* * *}$ & \\
\hline New Zealand-Sweden & $-2.112474^{* *}$ & -19.96549 *** & $-5.669287 * * *$ & $-13.44838^{* * *}$ & \\
\hline \multicolumn{5}{|c|}{$\begin{array}{l}\text { Note(s): DF-GLS test hypothesis: } H_{0}: \text { series contains a unit root } H_{1}: \text { series is stationary; Case II: constant } \\
\text { and linear trend } \\
\text { *** significant at } 1 \% \text { level; } * * \text { significant at } 5 \% \text { level; * significant at } 10 \% \text { level }\end{array}$} & $\begin{array}{r}\text { Table } \mathbf{1} \text {. } \\
\text { DF-GLS test results for } \\
\text { individual series }\end{array}$ \\
\hline
\end{tabular}

fundamentals. However, the speed of adjustment is low and ranges between 1 and $6 \%$. In the short run, positive changes in the money supply differential lead to a real exchange rate appreciation in the majority of cases. However, the real exchange rate depreciates in response to increases in the interest rate differential. Likewise, expectations of higher inflation rates cause the real exchange rate to depreciate, but this effect is not significant. The output differential is only significant in a few cases, when a higher differential leads to a depreciation of the real exchange rate. In the long run, most of the standard fundamentals and the inflation expectation variable are insignificant, which implies that there is no long-run relationship linking the real exchange rate to fundamentals.

Table 4 reports some diagnostic tests. The presence of serial correlation and parameter instability cast doubts on the data congruence of the model and motivates the estimation of the 


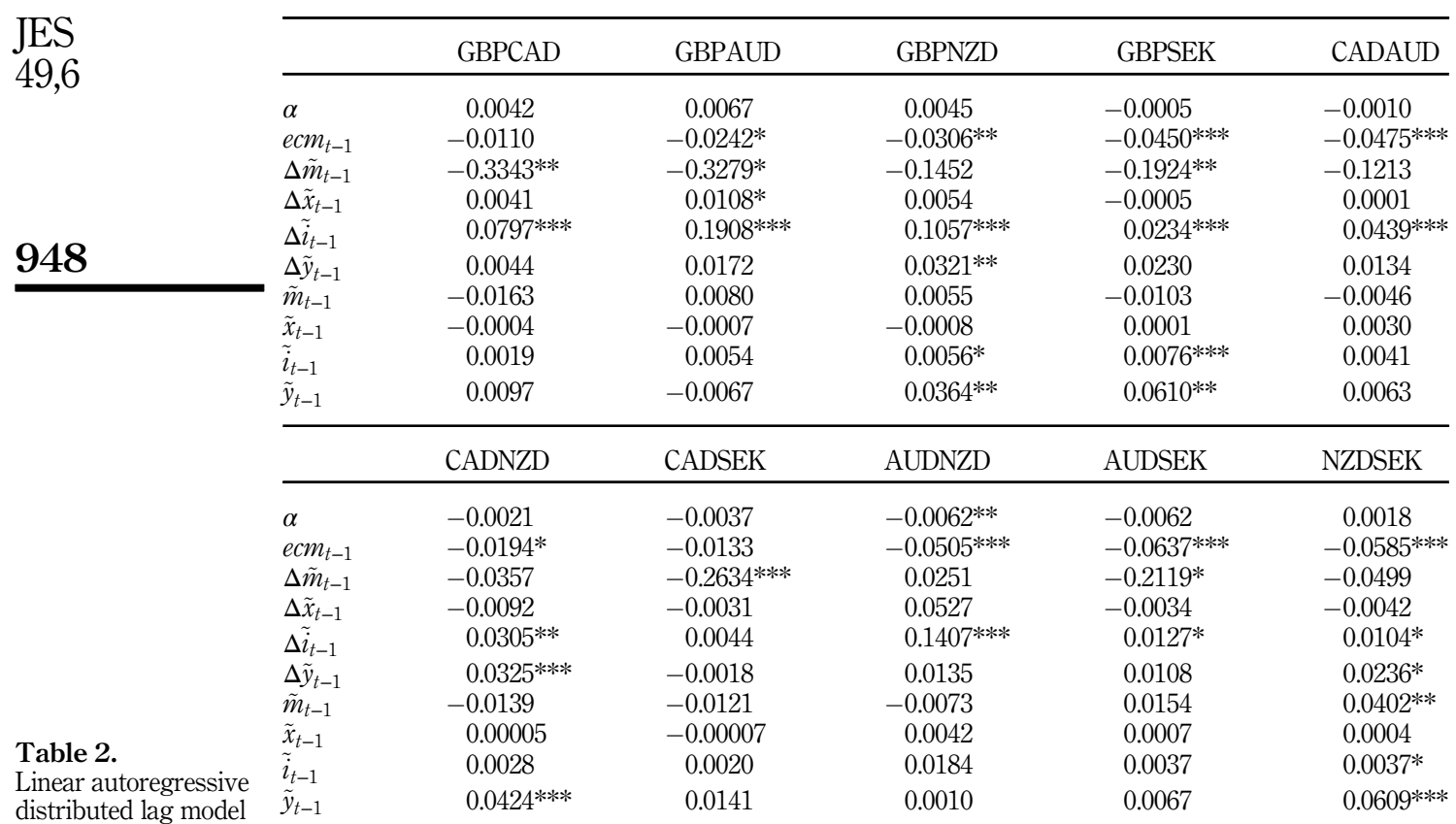

results with market $\quad$ Note(s): *significant at 10\% level, **significant at $5 \%$ level, ***significant at $1 \%$ level. Standard errors in expectations parentheses

nonlinear model. The results of the BDS test (not reported) on the individual series and on the ARDL model residuals indicate significance at the $1 \%$ level in all cases, which implies nonlinear dependence; this evidence motivates our choice of estimating a NARDL model next.

\subsection{Results for the NARDL (nonlinear ARDL) model}

The estimates of the NARDL specifications including market- and survey-based inflation expectations in turn are reported in Tables 5 and 6, respectively. It appears that, when nonlinearities are taken into account, evidence can be obtained of mean reversion to a long-run relationship between the real exchange rate and key fundamentals as implied by the negative and significant coefficient on the adjustment term $\mathrm{ecm}_{t-1}$. As for the short-run dynamics, in those cases when the estimated coefficients are significant they indicate that both positive and negative money supply and output changes lead to a real exchange rate appreciation, while both positive and negative interest rate changes lead to an exchange rate depreciation. This finding confirms the presence of short-run asymmetric effects of these variables.

Unlike in the linear ARDL, the inflation expectation differential now also plays a role and has an asymmetric effect; more precisely, only positive inflation expectation changes are significant and cause an appreciation of the real exchange rate. In other words, deviations from PPP occur only when the market expects inflation to be higher than the target rate in the future, i.e. when the central bank lacks credibility. This supports the findings of other related studies reporting that higher inflation rates tend to cause an appreciation in the exchange rate owing to agents' expectations that monetary authorities will reduce inflation back to target in the future (Clarida and Waldmann, 2008). Further, it appears that credibility changes frequently over time, but that there is only little connection between a loss in central bank credibility and economic shocks (Bordo and Siklos, 2015). Finally, lack of transparency on the 


\begin{tabular}{|c|c|c|c|c|c|c|}
\hline & GBPCAD & GBPAUD & GBPNZD & GBPSEK & CADAUD & Nonlinearities \\
\hline$\alpha$ & $0.0065^{*}$ & 0.0095 & 0.0050 & 0.0006 & 0.0020 & \\
\hline$e c m_{t-1}$ & -0.0174 & $-0.0355^{* *}$ & $-0.0327 * *$ & $-0.0508^{* * * *}$ & $-0.0423^{* *}$ & asymmetric \\
\hline$\Delta \tilde{m}_{t-1}$ & $-0.3237^{* *}$ & $-0.3102^{*}$ & -0.1667 & $-0.1966^{* *}$ & -0.1896 & adiustment \\
\hline$\Delta \tilde{x}_{t-1}$ & -0.0015 & 0.0012 & $0.0049 * *$ & -0.0010 & -0.0011 & \\
\hline$\Delta \tilde{i}_{t-1}$ & $0.0804 * * *$ & $0.1956^{* * * *}$ & $0.0922 * * *$ & $0.0225^{* * * *}$ & 0.0457 *** & \\
\hline$\Delta \tilde{y}_{t-1}$ & 0.0061 & 0.0152 & $0.0335^{* *}$ & 0.0226 & $0.0176^{*}$ & \\
\hline$\tilde{m}_{t-1}$ & $0.0175^{*}$ & 0.0123 & -0.0021 & -0.0110 & -0.0123 & 94 \\
\hline$\tilde{x}_{t-1}$ & -0.0017 & $-0.0054^{*}$ & 0.0002 & -0.0021 & -0.0008 & \\
\hline$\tilde{i}_{t-1}$ & 0.0040 & $0.0066^{*}$ & $0.0059 *$ & $0.0076^{* * *}$ & 0.0046 & \\
\hline \multirow[t]{2}{*}{$\tilde{y}_{t-1}$} & 0.0139 & -0.0058 & $0.0419 * *$ & $0.0606^{* * *}$ & 0.0143 & \\
\hline & CADNZD & CADSEK & AUDNZD & AUDSEK & NZDSEK & \\
\hline$\alpha$ & -0.0038 & -0.0032 & $-0.0105^{* * * *}$ & -0.0065 & 0.0006 & \\
\hline ecm $m_{t-1}$ & $-0.0232 * *$ & -0.0118 & -0.0520 *** & $-0.0636^{* * *}$ & $-0.0563^{* * *}$ & \\
\hline$\Delta \tilde{m}_{t-1}$ & -0.0299 & $-0.2546^{* * *}$ & -0.0587 & $-0.2154^{*}$ & -0.0333 & \\
\hline$\Delta \tilde{x}_{t-1}$ & 0.0001 & -0.0001 & -0.0032 & 0.0000 & 0.0053 & \\
\hline$\Delta \tilde{i}_{t-1}$ & $0.0320 * *$ & 0.0057 & $0.0947^{* * * *}$ & $0.0148^{* *}$ & $0.0115^{* *}$ & \\
\hline$\Delta \tilde{y}_{t-1}$ & $0.0312^{* * * *}$ & -0.0024 & 0.0076 & 0.0095 & $0.0260^{* *}$ & \\
\hline$\tilde{m}_{t-1}$ & 0.0103 & -0.0124 & -0.0136 & 0.0150 & $0.0406^{* *}$ & \\
\hline$\tilde{x}_{t-1}$ & -0.0003 & 0.0015 & $-0.0079 * *$ & 0.0000 & 0.0052 & \\
\hline$\tilde{i}_{t-1}$ & 0.0022 & 0.0014 & $0.0164^{* *}$ & 0.0034 & 0.0031 & L1 \\
\hline$\tilde{y}_{t-1}$ & $0.0407 * * *$ & 0.0129 & -0.0076 & 0.0037 & $0.0687 * * *$ & distributed lag model \\
\hline \multicolumn{7}{|c|}{$\begin{array}{l}\text { Note(s): *significant at } 10 \% \text { level, **significant at } 5 \% \text { level, ***significant at } 1 \% \text { level. Standard errors in results with survey } \\
\text { parentheses }\end{array}$} \\
\hline
\end{tabular}

part of monetary authorities increases exchange rate volatility (Dominguez, 1998). In our case, a positive (negative) sign for the coefficient on the negative partial sum component means that convergence (divergence) between expected future inflation between the two countries will lead to depreciation (appreciation) of the real exchange rate. For most exchange rates, changes in inflation expectations lead to an appreciation, regardless of whether inflation expectations converge or not. Further, only one of the partial sum components has a significant short-run effect. Finally, the adjustment speed ranges between 2 and $14 \%$ and is therefore up to three times faster than in the linear ARDL models and slightly faster in the model including survey-based expectations.

Table 7 reports the long-run asymmetric coefficients associated with positive and negative changes in the independent variables. It can be seen that positive (negative) money supply shocks have a negative (positive) impact, with the positive multipliers being greater than the negative ones. Both positive and negative interest rate shocks have a positive effect. Also, both types of inflation expectation shocks cause an exchange rate appreciation, while the effect of positive and negative output shocks on the real exchange rate varies. Finally, negative shocks to fundamentals or inflation expectations have a greater impact than positive ones, which is consistent with the evidence reported by other studies on the presence of asymmetries (Holmes and Wang, 2006). On the whole, money supply and output shocks have the largest long-run effects, but interest rate and inflation expectation shocks also have a significant impact on real exchange rate deviations from PPP and the adjustment process to the PPP equilibrium. In addition, changes in surveybased expectations have a more sizable impact than those in market-based ones.

The results of the Wald tests for symmetry of both the short- and long-run parameters (required as part of the NARDL procedure) are reported in Table 8 and imply a rejection of the null of parameter symmetry, which confirms the presence of nonlinearities. As noted earlier, there are three types of possible asymmetries in the NARDL model. The first is reaction 
JES
49,6

950

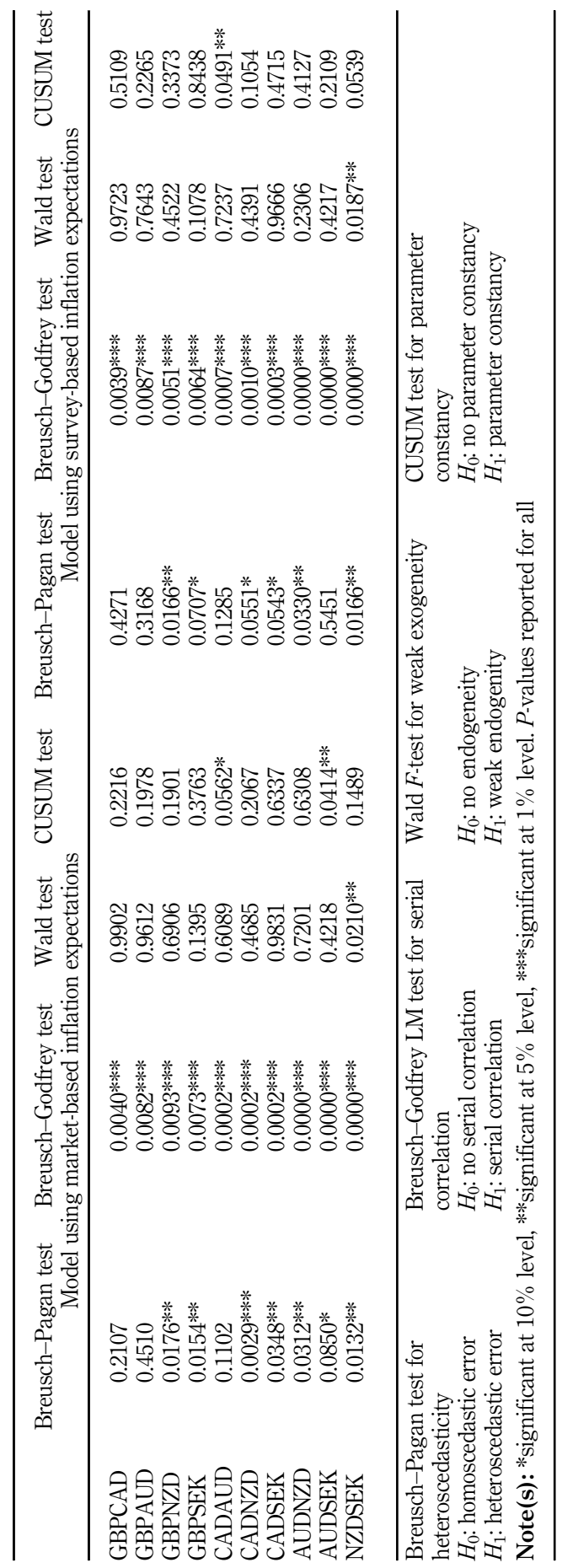

Table 4.

ARDL model

specification tests 


\begin{tabular}{|c|c|c|c|c|c|c|}
\hline & GBPCAD & GBPAUD & GBPNZD & GBPSEK & CADAUD & Nonlinearities \\
\hline$\alpha$ & $0.0535^{* * *}$ & $0.0421^{* *}$ & $0.0712^{* *}$ & $0.0385^{* * *}$ & $0.0448 * *$ & asvmmetric \\
\hline$e c m_{t-1}$ & $-0.0495^{* * *}$ & $-0.0323^{* *}$ & $-0.0320^{* *}$ & $-0.0964^{* * * *}$ & $-0.0812^{* * *}$ & asy $11110 \mathrm{li}$ \\
\hline$\Delta q_{t-1}$ & $0.1209 * *$ & $0.1036^{*}$ & $0.1566^{* * * *}$ & 0.0590 & $0.2128^{* * *}$ & adjustment \\
\hline$\Delta \tilde{m}_{t-1}^{+}$ & $-0.3480 * *$ & $-0.3823^{* *}$ & 0.0736 & $-0.3515^{*}$ & 0.1158 & \\
\hline$\Delta \tilde{m}_{t-1}^{-1}$ & -0.5562 & $-5.0506^{* * *}$ & -0.0221 & -0.2752 & -1.1064 & \\
\hline$\Delta \tilde{x}_{t-1}^{+-1}$ & $-0.0140 *$ & $-0.0249 * *$ & $-0.0007^{* *}$ & -0.0041 & $0.0235^{* * * *}$ & 951 \\
\hline$\Delta \tilde{x}_{t-1}^{-1}$ & 0.0040 & $0.0159 *$ & 0.0000 & 0.0067 & -0.0027 & \\
\hline$\widetilde{\Delta} i_{t-1}^{+}$ & 0.0298 & $0.1516^{* * *}$ & 0.0116 & $-0.0120^{*}$ & 0.0169 & \\
\hline$\Delta \tilde{i}_{t-1}^{-1}$ & 0.0131 & 0.0250 & $0.0429 *$ & $0.0646 * * *$ & 0.0151 & \\
\hline$\Delta \tilde{y}_{t-1}^{+-1}$ & -0.0002 & -0.0148 & -0.0310 & 0.0172 & -0.0119 & \\
\hline$\Delta \tilde{y}_{t-1}^{-}$ & -0.0016 & 0.0292 & 0.0086 & 0.0061 & $-0.0528^{*}$ & \\
\hline$\tilde{m}_{t-1}^{+-1}$ & $-0.0767 * * *$ & -0.0303 & -0.0398 & $-0.0907 * *$ & $-0.0810^{* *}$ & \\
\hline$\tilde{m}_{t-1}^{-1}$ & $0.2276^{* * *}$ & 1.1015 & $0.0377^{*}$ & $0.0677^{*}$ & 0.2629 & \\
\hline$\tilde{x}_{t-1}^{+-1}$ & -0.0020 & -0.0061 & $-0.0004^{* *}$ & 0.0002 & -0.0005 & \\
\hline$\tilde{x}_{t-1}^{-}$ & 0.0002 & -0.0039 & 0.0000 & 0.0017 & 0.0125 & \\
\hline$\tilde{i}_{t-1}^{+-1}$ & -0.0020 & 0.0084 & -0.0131 & 0.0039 & 0.0041 & \\
\hline$\tilde{i}_{t-1}^{-}$ & -0.0003 & 0.0036 & 0.0059 & $0.0155^{*}$ & 0.0097 & \\
\hline $\begin{array}{l}t-1 \\
\tilde{y}_{t-1}^{+}\end{array}$ & -0.0119 & -0.0213 & 0.0369 & -0.0146 & -0.0119 & \\
\hline \multirow[t]{2}{*}{$\tilde{y}_{t-1}^{-1}$} & 0.0975 & 0.0314 & 0.0028 & 0.0689 & 0.0571 & \\
\hline & CADNZD & CADSEK & AUDNZD & AUDSEK & NZDSEK & \\
\hline$\alpha$ & -0.0047 & $-0.0087 * *$ & $0.0231 * *$ & $-0.0260 * * *$ & -0.0016 & \\
\hline$e c m_{t-1}$ & $-0.0220^{*}$ & $-0.0219 * *$ & $-0.1404^{* * *}$ & $-0.0751 * * *$ & $-0.0772^{* * * *}$ & \\
\hline$\Delta q_{t-1}$ & $0.2022^{* * * *}$ & $0.1597^{* * * *}$ & $0.2957 * * *$ & $0.2370^{\text {*** }}$ & $0.2639 * * *$ & \\
\hline$\Delta \tilde{m}_{t-1}^{+}$ & 0.1896 & $-0.9054^{* *}$ & -0.2036 & -0.0050 & -0.1541 & \\
\hline$\Delta \tilde{m}_{t-1}^{-1}$ & -0.8428 & -0.1397 & 0.2285 & 0.0004 & -0.0114 & \\
\hline$\Delta \tilde{x}_{t-1}^{+-1}$ & 0.0161 & 0.0077 & $0.1314^{* * * *}$ & -0.0052 & 0.0099 & \\
\hline$\Delta \tilde{x}_{t-1}^{-1}$ & 0.0171 & 0.0141 & -0.0272 & $0.0138 * * *$ & -0.0006 & \\
\hline$\widetilde{\Delta} i_{t-1}^{+-1}$ & -0.0498 & -0.0086 & -0.0485 & -0.0011 & -0.0015 & \\
\hline$\Delta \tilde{i}_{t-1}^{t-1}$ & -0.0064 & 0.0060 & 0.0270 & $0.1252^{* * *}$ & $0.0767^{* * * *}$ & \\
\hline$\Delta \tilde{y}_{t-1}^{+}$ & -0.0088 & 0.0036 & -0.0118 & -0.0427 & 0.0022 & \\
\hline$\Delta \tilde{y}_{t-1}^{-}$ & -0.0169 & 0.0060 & 0.0198 & 0.0124 & -0.0236 & \\
\hline$\tilde{m}_{t-1}^{+-1}$ & -0.0048 & $1.3986^{* * * *}$ & 0.1098 & 0.0000 & -0.1236 & \\
\hline$\tilde{m}_{t-1}^{-1}$ & 0.0916 & -0.0229 & $0.0693^{* * * *}$ & -0.0004 & $0.0325^{*}$ & \\
\hline$\tilde{x}_{t-1}^{+-1}$ & -0.0005 & -0.0065 & $-0.0279 *$ & 0.0024 & -0.0003 & \\
\hline$\tilde{x}_{t-1}^{--1}$ & -0.0004 & -0.0078 & -0.0193 & -0.0011 & -0.0008 & \\
\hline$\tilde{i}_{t-1}^{+-1}$ & 0.0267 & -0.0016 & 0.0096 & 0.0026 & 0.0007 & \\
\hline $\begin{array}{l}\stackrel{t}{t-1}_{i_{t-1}^{-}}^{-} \\
\tilde{i}_{t}\end{array}$ & -0.0009 & 0.0077 & -0.0068 & -0.0095 & 0.0014 & Table 5. \\
\hline$\tilde{y}_{t-1}^{+-1}$ & 0.0295 & 0.0155 & 0.0269 & 0.0355 & -0.0064 & $\begin{array}{l}\text { Nonlinear } \\
\text { autoregressive }\end{array}$ \\
\hline$\tilde{y}_{t-1}^{-}$ & 0.0029 & 0.0253 & $-0.0384^{* *}$ & 0.0194 & $0.0991^{* * *}$ & $\begin{array}{l}\text { autoregressive } \\
\text { distributed lag model }\end{array}$ \\
\hline \multicolumn{7}{|c|}{$\begin{array}{l}\text { Note(s): *significant at } 10 \% \text { level, **significant at } 5 \% \text { level, ***significant at } 1 \% \text { level. Standard errors in results with market } \\
\text { parentheses }\end{array}$} \\
\hline
\end{tabular}

asymmetry, namely asymmetry of the long-run coefficients, i.e. $\beta^{+} \neq \beta^{-}$, for which we find plenty of evidence. Of particular interest is the result that negative inflation expectation shocks have a more pronounced effect than positive ones, which suggests that central banks are perceived as more credible when aiming to reduce (rather than increase) inflation. The second type is impact asymmetry of the short-run coefficients on the first differences of the independent variables, i.e. $\Delta x^{+} \neq \Delta x^{-}$. Our results are less supportive of the existence of such asymmetries. The third type is dynamic adjustment asymmetry combining reaction and 


\begin{tabular}{|c|c|c|c|c|c|c|}
\hline \multirow{6}{*}{$\begin{array}{l}\mathrm{JES} \\
49,6\end{array}$} & & GBPCAD & GBPAUD & GBPNZD & GBPSEK & CADAUD \\
\hline & $\alpha$ & $0.0506 * * *$ & -0.0013 & $0.0232 *$ & $0.0270 * *$ & $0.0448^{* * *}$ \\
\hline & $e c m_{t-1}$ & $-0.0569^{* * *}$ & $-0.0684^{* * *}$ & $-0.0642^{* * * *}$ & $-0.0743^{* * *}$ & $-0.0812^{* * * *}$ \\
\hline & $\Delta q_{t-1}$ & 0.1016* & $0.1600 * * *$ & $0.1450^{* * *}$ & 0.0582 & $0.2128 * * *$ \\
\hline & $\Delta \tilde{m}_{t-1}^{+}$ & $-0.3580 * *$ & -0.0017 & -0.1666 & $-0.3763^{*}$ & 0.1158 \\
\hline & $\Delta \tilde{m}_{t-1}^{-1-1}$ & $-0.7340 * *$ & $-1.3426^{*}$ & $-0.8949 *$ & -0.2473 & -1.1064 \\
\hline \multirow{30}{*}{952} & $\Delta \tilde{x}_{t-1}^{+-}$ & 0.0045 & 0.0032 & 0.0007 & 0.0014 & $0.0235^{* * *}$ \\
\hline & $\begin{array}{l}\Delta \tilde{x}_{t-1}^{-} \\
\widetilde{\Delta i_{t}^{+}}\end{array}$ & $\begin{array}{l}0.0007 \\
0.0271\end{array}$ & $\begin{array}{r}0.0022 \\
-0.0211\end{array}$ & $\begin{array}{l}0.0014 \\
0.0126\end{array}$ & $\begin{array}{c}0.0005 \\
-0.0123^{*}\end{array}$ & $\begin{array}{r}-0.0027 \\
0.0169\end{array}$ \\
\hline & $\begin{array}{l}\Delta i_{t-1} \\
\Delta \tilde{i}^{-}\end{array}$ & 0.0098 & $0.0857 * *$ & $0.0421^{*}$ & $0.0685^{* * * *}$ & 0.0151 \\
\hline & $\begin{array}{l}\Delta t_{t-1} \\
\Delta \tilde{y}_{t-1}^{+}\end{array}$ & 0.0021 & -0.0144 & -0.0183 & 0.0172 & -0.0119 \\
\hline & $\Delta \tilde{y}_{t-1}^{-}$ & -0.0038 & 0.0282 & 0.0212 & 0.0088 & $-0.0528^{*}$ \\
\hline & $\tilde{m}_{t-1}^{+}$ & $-0.0716^{* * *}$ & $0.0497^{* *}$ & $-0.0605^{* *}$ & -0.0797 & $-0.0810^{* *}$ \\
\hline & $\tilde{m}_{t-1}^{l-1}$ & $0.2415^{* * * *}$ & 0.3199 & 0.1381 & 0.0348 & 0.2629 \\
\hline & $\tilde{x}_{t-1}^{+-1}$ & $-0.0041 * *$ & $-0.0087^{*}$ & $0.0034^{*}$ & -0.0019 & -0.0005 \\
\hline & $\tilde{x}_{t-1}^{-1}$ & $-0.0034^{*}$ & $-0.0141^{* *}$ & -0.0048 & -0.0015 & 0.0125 \\
\hline & $\tilde{i}_{t-1}^{+-1}$ & -0.0009 & $0.0175^{* *}$ & -0.0056 & 0.0032 & 0.0041 \\
\hline & $\tilde{i}_{t-1}^{-}$ & 0.0011 & $0.0120 * *$ & 0.0059 & 0.0091 & $0.0097^{* *}$ \\
\hline & $\begin{array}{l}t-1 \\
\tilde{y}_{t-1}^{+}\end{array}$ & -0.0176 & -0.0233 & $0.0041^{* *}$ & -0.0151 & -0.0119 \\
\hline & $\tilde{y}_{t-1}^{-1}$ & $0.1005^{*}$ & 0.0311 & $0.0021^{*}$ & 0.0663 & 0.0571 \\
\hline & & CADNZD & CADSEK & AUDNZD & AUDSEK & NZDSEK \\
\hline & $\alpha$ & -0.0054 & $-0.0111 * *$ & $0.0251 * *$ & $-0.0254^{* * * *}$ & $-0.0225^{* * * *}$ \\
\hline & $e c m_{t-1}$ & $-0.0276^{* *}$ & $-0.0312^{* *}$ & $-0.1362 * * *$ & $-0.0801 * * * *$ & $-0.1300^{* * * *}$ \\
\hline & $\Delta q_{t-1}$ & $0.1898^{* * *}$ & $0.1740^{* * *}$ & $0.2859 * * *$ & $0.2213^{* * * *}$ & $0.2256^{* * * *}$ \\
\hline & $\Delta \tilde{m}_{t-1}^{+}$ & 0.1353 & $-0.8615^{* *}$ & -0.1658 & -0.0040 & -0.2111 \\
\hline & $\Delta \tilde{m}_{t-1}^{-1}$ & -0.8081 & $-0.1420^{*}$ & 0.2398 & 0.0002 & 0.1811 \\
\hline & $\Delta \tilde{x}_{t-1}^{+-1}$ & 0.0010 & 0.0012 & $0.0095 * *$ & 0.0013 & 0.0004 \\
\hline & $\Delta \tilde{x}_{t-1}^{-1}$ & 0.0031 & $0.0052 * *$ & -0.0038 & -0.0015 & $0.0116^{*}$ \\
\hline & $\widetilde{\Delta i_{t-1}^{+}}$ & -0.0589 & $-0.0097^{*}$ & $-0.1012^{* *}$ & -0.0042 & -0.0076 \\
\hline & $\Delta \tilde{i}_{t-1}^{-1}$ & 0.0064 & 0.0087 & -0.0081 & $0.1337 * * *$ & -0.0050 \\
\hline & $\Delta \tilde{y}_{t-1}^{+}$ & -0.0154 & 0.0007 & -0.0159 & -0.0376 & -0.0303 \\
\hline & $\Delta \tilde{y}_{t-1}^{-1}$ & -0.0254 & 0.0075 & $0.0248^{*}$ & 0.00709 & -0.0010 \\
\hline & $\tilde{m}_{t-1}^{+}$ & -0.0006 & 1.2173 *** & 0.1048 & 0.0000 & $0.1102^{* * *}$ \\
\hline & $\tilde{m}_{t-1}^{-}$ & 0.1446 & -0.0203 & $0.0885^{* * * *}$ & -0.0003 & -0.0119 \\
\hline & $\tilde{x}_{t-1}^{+-1}$ & -0.0018 & -0.0023 & $-0.0086^{* *}$ & -0.0036 & -0.0010 \\
\hline & $\tilde{x}_{t-1}^{-1}$ & -0.0018 & -0.0024 & $-0.0078^{* *}$ & -0.0012 & -0.0016 \\
\hline & $\tilde{i}_{t-1}^{+-1}$ & 0.0287 & -0.0008 & $0.0241^{*}$ & $0.0041^{*}$ & $0.0069 * *$ \\
\hline \multirow{3}{*}{$\begin{array}{l}\text { Table } 6 . \\
\text { Nonlinear } \\
\text { autoregressive } \\
\text { distributed lag model }\end{array}$} & $\begin{array}{l}\tilde{i}_{t-1}^{-1} \\
\tilde{i}_{t-1}^{-}\end{array}$ & 0.0016 & 0.0092 & 0.0109 & -0.0109 & 0.0039 \\
\hline & $\begin{array}{l}\tilde{y}_{t-1}^{+} \\
\end{array}$ & 0.0382 & 0.0219 & 0.0469 & -0.0337 & 0.0591 \\
\hline & $\tilde{y}_{t-1}^{-1}$ & 0.0108 & 0.0224 & $-0.0489^{* *}$ & -0.0140 & 0.0511 \\
\hline
\end{tabular}

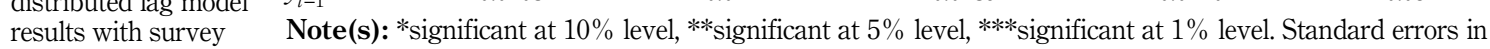
expectations parentheses

impact asymmetries in the error correction coefficient. Its estimated values are larger than those yielded by the linear model, and therefore, allowing for nonlinearities provides evidence of faster adjustment to the long-run equilibrium value implied by PPP.

4.4 NARDL model performance and mis-specification tests

To check the adequacy of the NARDL specification we conduct various tests. Table 9 reports the $F$-tests statistics of the bounds test using both the asymptotic and bootstrapped critical 


\begin{tabular}{|c|c|c|c|c|c|}
\hline Marke & $\begin{array}{l}\text { ations } \\
\text { GBPCAD }\end{array}$ & GBPAUD & GBPNZD & GBPSEK & CADAUD \\
\hline$L \tilde{m}^{+}$ & $-1.5509 * * * *$ & $-0.9359^{* * * *}$ & $-1.2431^{* *}$ & $-0.9409^{* * *}$ & $-0.9980^{* * * *}$ \\
\hline$L \tilde{m}^{-}$ & $4.6012^{* * *}$ & $34.0792^{* * * *}$ & $1.1780^{* *}$ & $0.7026^{* * *}$ & $3.2375^{* * * *}$ \\
\hline$\tilde{L}^{+}$ & $-0.0410 * * *$ & $0.2606 * * * *$ & $-0.4094^{* *}$ & $0.0407^{* * * *}$ & $0.0504 * * *$ \\
\hline$L \tilde{i}^{-}$ & $-0.0053^{* * * *}$ & $0.1116^{\text {**** }}$ & $0.1840^{* *}$ & $0.1606^{* * *}$ & $0.1201^{* * * *}$ \\
\hline$L \tilde{x}^{+}$ & $-0.0405^{* * *}$ & $-0.1890^{* * * *}$ & $-0.0130^{* *}$ & $0.0019 * * *$ & $-0.0057^{* * * *}$ \\
\hline$L \tilde{x}^{-}$ & $0.0042^{* * * *}$ & $-0.1198^{* * * *}$ & $-0.0024^{* *}$ & $0.0175^{* * *}$ & $0.1536^{* * * *}$ \\
\hline$L \tilde{y}^{+}$ & $-0.2412^{* * *}$ & $-0.6591^{* * * *}$ & $1.1541^{* *}$ & $-0.1515^{* * * *}$ & $-0.1465^{* * * *}$ \\
\hline \multirow[t]{2}{*}{$L \tilde{y}^{-}$} & $1.9712^{* * *}$ & $0.9730^{* * * *}$ & $0.0860^{* *}$ & $0.7143^{* * *}$ & $0.7028^{* * * *}$ \\
\hline & CADNZD & CADSEK & AUDNZD & AUDSEK & NZDSEK \\
\hline$L \tilde{m}^{+}$ & $-0.2172 *$ & $63.9348^{* *}$ & $0.7820^{* * * *}$ & $-0.0001^{* *}$ & $-1.6019 * * *$ \\
\hline$L \tilde{m}^{-}$ & $4.1573 *$ & $-1.0472 * *$ & $0.4933^{* * * *}$ & $-0.0047^{* * * *}$ & $0.4210 * * *$ \\
\hline$\tilde{L i}^{+}$ & $1.2105^{*}$ & $-0.0721 * *$ & $0.0687^{* * * *}$ & $0.0348^{* * * *}$ & $0.0094^{* * * *}$ \\
\hline$\tilde{L i}$ & $-0.0424^{*}$ & $0.3497 * *$ & $-0.0487^{* * * *}$ & $-0.1267^{* * * *}$ & $0.0186^{* * *}$ \\
\hline$L \tilde{x}^{+}$ & $-0.0215^{*}$ & $-0.2949 * *$ & $-0.1991^{* * * *}$ & $0.0323^{* * * *}$ & $-0.0035^{* * * *}$ \\
\hline$L \tilde{x}^{-}$ & $-0.0182 *$ & $-0.3545^{* *}$ & $-0.1373^{* * * *}$ & $-0.0140^{* * * *}$ & $-0.0098^{* * * *}$ \\
\hline$L \tilde{y}^{+}$ & $1.3395^{*}$ & $0.7086^{* *}$ & $0.1915^{* * * *}$ & $0.4726^{* * * *}$ & $-0.0830 * * *$ \\
\hline$\tilde{L}^{-}$ & $0.1305^{*}$ & $1.1570 * *$ & $-0.2732^{* * * *}$ & $-0.2587 * * *$ & $1.2847 * * *$ \\
\hline \multicolumn{6}{|c|}{ Survey expectations } \\
\hline & GBPCAD & GBPAUD & GBPNZD & GBPSEK & CADAUD \\
\hline$L \tilde{m}^{+}$ & $-1.2573^{* * * *}$ & $0.7271^{* * * *}$ & $-0.9426^{* * * *}$ & $-1.0727 * * *$ & $-0.9980^{* * * *}$ \\
\hline$L \tilde{m}^{-}$ & $4.2404^{* * * *}$ & $4.6771^{* * * *}$ & $2.1513^{* * * *}$ & $0.4684^{* * * *}$ & $3.2375^{* * * *}$ \\
\hline$\tilde{L i}^{+}$ & $-0.0161^{* * * *}$ & $0.2564 * * *$ & $-0.0874^{* * * *}$ & $0.0430^{* * * *}$ & $0.0504^{* * * *}$ \\
\hline$\tilde{L}^{-}$ & $0.0198^{* * * *}$ & $0.1747 * * *$ & $0.0917 * * *$ & $0.1223^{* * *}$ & $0.1201 * * *$ \\
\hline$L \tilde{x}^{+}$ & $-0.0711^{* * * *}$ & $-0.1274^{* * * *}$ & $0.0534^{* * * *}$ & $-0.0261^{* * *}$ & $-0.0057 * * *$ \\
\hline$L \tilde{x}^{-}$ & $-0.0594^{* * *}$ & $-0.2061^{* * * *}$ & $-0.0751^{* * * *}$ & $-0.0203^{* * *}$ & $0.1536^{* * *}$ \\
\hline$L \tilde{y}^{+}$ & $-0.3098^{* * * *}$ & $-0.3400 * * *$ & $0.0641^{* * *}$ & $-0.2033^{* * * *}$ & $-0.1465^{* * * *}$ \\
\hline \multirow[t]{2}{*}{$L \tilde{y}^{-}$} & $1.7651^{* * * *}$ & $0.3242 * * *$ & $0.0324 * * *$ & $0.8929 * * *$ & $0.7028^{* * * *}$ \\
\hline & CADNZD & CADSEK & AUDNZD & AUDSEK & NZDSEK \\
\hline $\operatorname{Lm}^{+}$ & $-0.0225^{* *}$ & $38.9586^{* * *}$ & $0.7693^{* * * *}$ & $-0.0001^{* * * *}$ & $0.8473^{* * * *}$ \\
\hline$L \tilde{m}^{-}$ & $5.2368^{* *}$ & $-0.6481^{* * *}$ & $0.6501^{* * * *}$ & $-0.0041^{* * * *}$ & $-0.0917 * * *$ \\
\hline$\tilde{L i}^{+}$ & $1.0408^{* * *}$ & $-0.0240 * * *$ & $0.1773^{* * * *}$ & $0.0507^{* * * *}$ & $0.05271^{* * * *}$ \\
\hline$L \tilde{i}^{-}$ & $0.0584^{* *}$ & $0.2948 * * *$ & $0.0803^{* * * *}$ & $-0.1358^{* * * *}$ & $0.0297^{* * *}$ \\
\hline$L \tilde{x}^{+}$ & $-0.0642^{* *}$ & $-0.0741^{* * *}$ & $-0.0633^{* * * *}$ & $-0.0445^{* * *}$ & $-0.0076^{* * *}$ \\
\hline$L \tilde{x}^{-}$ & $-0.0657^{* *}$ & $-0.0783^{* * * *}$ & $-0.0574^{* * * *}$ & $0.0154^{* * * *}$ & $-0.0121^{* * * *}$ \\
\hline$L \tilde{y}^{+}$ & $1.3815^{* *}$ & $0.7014^{* * * *}$ & $0.3448^{* * * *}$ & $0.4206^{* * * *}$ & $0.4548^{* * * *}$ \\
\hline$L \tilde{y}^{-}$ & $0.3920^{* *}$ & $0.7155^{* * * *}$ & $-0.3593^{* * * *}$ & $-0.1750^{* * * *}$ & $0.3929^{* * *}$ \\
\hline
\end{tabular}

Nonlinearities

and asymmetric adjustment

953

Survey expectations parentheses $L^{+}$and $L^{+}$denote the positive and negative long-run coefficients, which are defined by $\beta^{+}=-\frac{\theta^{+}}{\rho}$ and $\beta^{-}=-\frac{\theta^{-}}{\rho}$

values; the null hypothesis of no cointegration cannot be rejected in either case with the single exception of the CADNZD model.

Table 10 shows the lag selection and other diagnostic tests for serial correlation, ARCH effects and for parameter constancy; these confirm data congruency, unlike in the linear case and thus support the choice of a nonlinear model.

Next, we compare both the in-sample and out-of-sample performance of the previously estimated linear and nonlinear specifications. Table 11 reports the computed Clark and West 
Market expectations

Wald test for longrun symmetry
Wald test for shortrun symmetry
Survey expectations

Wald test for long- Wald test for short run symmetry run symmetry

$\begin{array}{rlllll} & \text { GBPCAD } & 0.0000^{* * *} & 0.0002 * * * & 0.0000^{* * *} & 0.0000^{* * *} \\ \mathbf{9 5 4} \text { GBPAUD } & 0.0018^{* * *} & 0.3750 & 0.0651^{*} & 0.0000^{* * * *} \\ & \text { GBPNZD } & 0.0280^{* *} & 0.0069^{* * *} & 0.0358^{* *} & 0.0003^{* * * *} \\ & \text { GBPSEK } & 0.0021^{* * *} & 0.0031^{* * *} & 0.0126^{* *} & 0.0148^{* * *} \\ & \text { CADAUD } & 0.0278^{* * *} & 0.0000^{* * *} & 0.0278^{* *} & 0.0000^{* * * *} \\ & \text { CADNZD } & 0.8779 & 0.0360^{* * *} & 0.7392 & 0.0729^{*} \\ & \text { CADSEK } & 0.0324^{* *} & 0.0000^{* * *} & 0.0489^{* *} & 0.0000^{* * * *} \\ \text { Table 8. } & \text { AUDNZD } & 0.0000^{* * *} & 0.0000^{* * *} & 0.0000^{* * *} & 0.0000^{* * * *} \\ & \text { AUDSEK } & 0.0081^{* * *} & 0.0000^{* * *} & 0.0117^{* *} & 0.0000^{* * *} \\ & \text { NZDSEK } & 0.7883 & 0.0117^{* * *} & 0.0005^{* * *} & 0.0000^{* * * *}\end{array}$

Table 8. symmetry *** significant at $1 \%$ level; ** significant at $5 \%$ level; * significant at $10 \%$ level

$F$-statistic for NARDL model (1) using market- $\quad F$-statistic for NARDL model (2) using surveybased inflation expectations based inflation expectations

\begin{tabular}{lcc}
\hline GBPCAD & $14.6989 * * *$ & $22.8373 * * *$ \\
GBPAUD & 0.7892 & $3.4263^{* *}$ \\
GBPNZD & $4.8728 * * *$ & $4.4447 * * *$ \\
GBPSEK & $9.6628^{* * *}$ & $6.3136^{* * *}$ \\
CADAUD & $4.8838^{* * *}$ & $4.8838^{* * *}$ \\
CADNZD & 0.0236 & 0.1111 \\
CADSEK & $4.6149 * * *$ & $3.9070^{* * *}$ \\
AUDNZD & $19.7235^{* * *}$ & $17.9692^{* * *}$ \\
AUDSEK & $7.0785 * * *$ & $6.4219 * * *$ \\
NZDSEK & 0.0722 & $12.3972 * * *$
\end{tabular}

Table 9.

Bounds test results using asymptotic and bootstrap critical values
Note(s): Asymptotic critical values: 10\%:3.09, 5\%:3.49, 1\%: 4.37

Bootstrap critical values: $10 \%: 2.85,5 \%: 3.15,1 \%: 3.77$

*** significant at $1 \%$ level; ** significant at $5 \%$ level; * significant at $10 \%$ level

\begin{tabular}{|c|c|c|c|c|c|c|c|}
\hline & \multirow[b]{2}{*}{$\begin{array}{l}\text { Selected } \\
\quad \text { lag }\end{array}$} & \multicolumn{3}{|c|}{$\begin{array}{l}\text { Model using market-based inflation } \\
\text { expectations }\end{array}$} & \multicolumn{3}{|c|}{$\begin{array}{l}\text { Model using survey-based inflation } \\
\text { expectations }\end{array}$} \\
\hline & & $\begin{array}{l}\mathrm{ARCH} \\
\text { effects }\end{array}$ & LM test & $\begin{array}{l}\text { CUSUM } \\
\text { test }\end{array}$ & $\begin{array}{l}\mathrm{ARCH} \\
\text { effects }\end{array}$ & LM test & $\begin{array}{l}\text { CUSUM } \\
\text { test }\end{array}$ \\
\hline BPCAD & 1 & 0.0633 & 0.5490 & $0.0000^{\circ}$ & 0.1689 & 0.3520 & $0.0000^{* * * *}$ \\
\hline 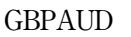 & 1 & & & & & & $0.0000^{* * * *}$ \\
\hline GBPNZD & 1 & 0.8188 & 0.2955 & $0.0000 * * *$ & 0.2004 & 0.2689 & $0.0000^{* * * *}$ \\
\hline GBPSEK & 1 & 0.0874 & 0.8898 & 0.0000 & 0.0866 & 0.7452 & $0.0002^{* * * *}$ \\
\hline ADAUD & 1 & 0.0658 & 0.2394 & 0.0000 & 0.0658 & 0.2394 & $0.0000^{* * * *}$ \\
\hline CADNZD & 1 & 0.3472 & 0.6370 & 0.0000 & 0.1660 & 0.9497 & $0.0000 * * * *$ \\
\hline CADSEK & 1 & 0.3 & 0.3 & 0.00 & & 0.4125 & $0.0000 * * *$ \\
\hline AUDNZD & 1 & 0.1189 & 0.7916 & $0.0000^{\circ}$ & 0.0967 & 0.7057 & $0.0000 * * * *$ \\
\hline AUDSEK & 1 & 0.7500 & 0.4914 & $0.0002 * * *$ & 0.3815 & 0.3978 & $0.0001^{* * * *}$ \\
\hline NZDSEK & 1 & 0.9090 & 0.9965 & $0.0002^{* * * *}$ & 0.4234 & 0.4723 & $0.0000^{* * * *}$ \\
\hline \multicolumn{2}{|c|}{$\begin{array}{l}\text { LM test for ARCH effects } \\
H_{0}: \text { no ARCH effects } \\
H_{1}: \text { no ARCH effects }\end{array}$} & $\begin{array}{l}\text { LM test for } \\
H_{0}: \text { no seria } \\
H_{1}: \text { serial co }\end{array}$ & $\begin{array}{l}\text { ial correla } \\
\text { rrelation } \\
\text { lation }\end{array}$ & & $\begin{array}{l}\text { CUSUM te } \\
H_{0}: \text { no pare } \\
H_{1} \text { : parame }\end{array}$ & $\begin{array}{l}\text { i paramet } \\
\text { er constar } \\
\text { constancy }\end{array}$ & $\begin{array}{l}\text { constancy } \\
\text { y }\end{array}$ \\
\hline \multicolumn{8}{|c|}{ Note(s): $* * *$ significant at $1 \%$ level; $* *$ significant at $5 \%$ level; $*$ significant at 1} \\
\hline
\end{tabular}




\begin{tabular}{|c|c|c|c|c|c|}
\hline & \multicolumn{2}{|c|}{$\begin{array}{l}\text { CW statistic for models using market-based } \\
\text { inflation expectations }\end{array}$} & \multicolumn{2}{|c|}{$\begin{array}{l}\text { CW statistic for models using survey-based } \\
\text { inflation expectations }\end{array}$} & \multirow{2}{*}{$\begin{array}{r}\text { Nonlinearities } \\
\text { and } \\
\text { asymmetric } \\
\text { adjustment }\end{array}$} \\
\hline & $\begin{array}{l}\text { In-sample } \\
\text { performance }\end{array}$ & $\begin{array}{l}\text { Out-of-sample } \\
\text { performance }\end{array}$ & $\begin{array}{l}\text { In-sample } \\
\text { performance }\end{array}$ & $\begin{array}{l}\text { Out-of-sample } \\
\text { performance } \\
\end{array}$ & \\
\hline $\mathrm{BPCAD}$ & $3.03387487 * *$ & $3.39208724 * *$ & $4.58454583 * *$ & $3.38925156 * *$ & \\
\hline GBPAUD & $10.6863519 * *$ & & 10.52 & & \\
\hline GBPNZD & $11.6279898^{* *}$ & $12.2931721^{* *}$ & $2.81195405^{\text {** }}$ & $11.4778461^{* *}$ & Tu \\
\hline GBPSEK & $4.13871062^{* * *}$ & $16.3711914 * *$ & $3.8333045^{* *}$ & $13.0607168 * *$ & \\
\hline CADAUD & $2.44888098 * *$ & $15.4383316^{* *}$ & $3.39201903 * *$ & $21.2617149 * *$ & \\
\hline CADNZD & $2.90834757 * *$ & $5.36748511^{* * *}$ & $2.71442531 * *$ & $5.88069641 * *$ & \\
\hline CADSEK & $5.50953645^{* *}$ & $2.63149382 * *$ & $5.44269445 * *$ & $1.79559331 * *$ & \\
\hline AUDNZD & $42.7264363 * *$ & $48.4560815^{* *}$ & $3.48202603 * *$ & $35.0526318 * *$ & \\
\hline AUDSEK & $2.49953189 * *$ & $4.98907343^{* *}$ & $2.49985165^{* *}$ & $5.45426571^{* *}$ & Tab \\
\hline NZDSEK & $4.04552116^{* *}$ & $26.2182514^{* * *}$ & $3.99499817 * *$ & $31.502991^{* *}$ & \\
\hline \multicolumn{6}{|c|}{$\begin{array}{lr}\text { Note(s): } * * \text { indicates significance at normal critical value of } 5 \%: 1.645 & \text { comparing in-sample } \\
\text { CW }=\text { Clark and West test statistic for comparing the MSPE of the NARDL model with the MSPE of the linear } & \text { and out-of-sample } \\
\text { ARDL model } & \text { forecasting } \\
t \text {-Test hypotheses } & \text { performance of the } \\
\mathrm{H}_{0}: M S P E_{A R D L}=M S P E_{N A R D L} & \text { linear and nonlinear } \\
\mathrm{H}_{1}: M S P E_{A R D L}>M S P E_{N A R D L} & \text { models }\end{array}$} \\
\hline
\end{tabular}

statistics for all models; as can be seen, these indicate that the nonlinear model outperforms the linear one in all cases.

As a final step, we compute the half-lives for both the ARDL and NARDL models and report them in Table 12. It can be seen that in the former case they are estimated to be between 1 and 5 years, consistently with other similar studies (Rogoff, 1996), whilst in the latter case they are substantially shorter and range between 0.4 and 1.5 years (Norman, 2010). In particular, the half-lives computed from the NARDL model including survey expectations are almost all below one year, which provides further evidence that a nonlinear framework captures better the adjustment towards PPP.

\section{Conclusions}

The aim of this paper was to shed new light on the PPP puzzle by estimating a model of the real exchange rates including standard fundamentals as well as two alternative measures of

\begin{tabular}{lcccc}
\hline & \multicolumn{2}{c}{ ARDL model } & \multicolumn{3}{c}{ NARDL model } \\
& Market expectations & Survey expectations & Market expectations & Survey expectations \\
\hline GBPCAD & 5.22 & 3.29 & 1.14 & 0.99 \\
GBPAUD & 2.36 & 1.60 & 1.76 & 0.82 \\
GBPNZD & 1.86 & 1.74 & 1.78 & 0.87 \\
GBPSEK & 1.25 & 1.11 & 0.57 & 0.75 \\
CADAUD & 1.19 & 1.34 & 0.68 & 0.68 \\
CADNZD & 2.95 & 2.46 & 2.60 & 2.06 \\
CADSEK & 4.31 & 4.87 & 2.61 & 0.82 \\
AUDNZD & 1.11 & 1.08 & 0.38 & 0.69 \\
AUDSEK & 0.88 & 0.88 & 0.74 & 0.41 \\
NZDSEK & 0.96 & 1.00 & 0.72 &
\end{tabular}

Note(s): Half-lives are calculated using the formula $\ln (0.5) / \ln (\rho)$; where $\rho$ is the speed of reversion and are the ARDL and NARDL expressed in years 
JES

49,6

956

inflation expectations in the specific case of five countries that have adopted inflation targeting (UK, Canada, Australia, New Zealand, Sweden). In particular, both a benchmark linear ARDL model and a NARDL specification are estimated.

The analysis yields two key findings. First, consistently with other studies (e.g. Taylor et al., 2001; Baum et al., 2001; Sollis et al., 2002), it suggests that a nonlinear framework is more appropriate to capture the behaviour of real exchange rates given the presence of asymmetries both in the long and short run. The speed of adjustment towards the PPP-implied long-run equilibrium is three times faster in a nonlinear framework, which provides much stronger evidence in support of PPP. The focus on linearities and the estimation of a NARDL model, which is shown to outperform the linear ARDL model both within sample and out of sample, is an important contribution to the existing literature which has rarely applied this type of framework; the choice of an appropriate econometric method also makes the policy implications of the analysis more reliable. The finding of an asymmetric impact of real, nominal and credibility shocks on the real exchange rate in both the short and the long run stands in contrast to most of the literature, which only finds a limited long-run impact of nominal shocks on the real exchange rate (Clarida and Gali, 1994; Lee and Chinn, 1998). In particular, our evidence that nominal shocks have a significant impact on the real exchange rate implies that policymakers can influence it in the long run through their actions and thus improve international competitiveness (Kutan and Dibooglu, 1998). Second, it highlights the role of inflation expectations, which is often overlooked in models including only standard fundamentals. In particular, survey-based ones appear to have a more sizable effect than market-based ones and to be more informative about the degree of credibility of a central bank and the possible impact of monetary policy on the real exchange rate. This confirms the findings of Ranchhod (2003), who reported that shocks to survey expectations can strongly influence the inflation rate in the inflation targeting regime, and of Bauer (2015), who found that survey measures are strongly correlated with variations in the interest rate and news about other macroeconomic variables, which makes them more representative of the perceived degree of central bank credibility.

Our results are also similar to those by Ding and Kim (2012) in the sense that we find ample evidence for the validity of PPP in inflation targeting countries. However, the present study extends theirs by identifying some of the economic variables influencing the real exchange rate under inflation targeting and also by allowing for nonlinearities and asymmetric adjustment to PPP by estimating a NARDL model. Since inflation expectations can cause deviations from PPP and affect the adjustment process it is clearly crucial that monetary authorities achieve a high degree of credibility and adopt appropriate policies to manage them and thus currency fluctuations effectively (Baharumshah et al., 2017). The evidence about the presence of nonlinearities and asymmetric shocks to PPP represents useful information for central banks to develop appropriate monetary policy strategies to counteract economic shocks (Lavesson, 2011). The inflation targeting framework has proven to be generally successful and therefore is also well placed in this respect.

\section{Note}

1. The official dates when inflation targeting was adopted in each country are as follows: UK - October 1992; Canada - February 1991; Australia - June 1993; New Zealand - December 1989; Sweden January 1993.

\section{References}

Allsopp, C., Kara, A. and Nelson, E. (2006), "United Kingdom inflation targeting and the exchange rate", The Economic Journal, Vol. 116 No. 512, pp. F232-F244.

Ariff, M. and Zarei, A. (2015), "Parity theorems revisited: an ARDL bounds test witn non-parity factors", Asian Academy of Management Journal of Accounting and Finance, Vol. 11 No. 1, pp. 1-26. 
Arize, A.C., Malindretos, J. and Igwe, E.U. (2017), "Do exchange rate changes improve the trade balance: an asymmetric nonlinear cointegration approach", International Review of Economics and Finance, Vol. 49, pp. 313-326.

Baharumshah, A.Z., Soon, S.V. and Wohar, M.E. (2017), "Markov-switching analysis of exchange rate pass-through: perspective from Asian countries", International Review of Economics and Finance, Vol. 51, pp. 245-257.

Bahmani-Oskooee, M., Kutan, A.M. and Zhou, S. (2008), "Do real exchange rates follow a nonlinear mean reverting process in developing countries?", Southern Economic Journal, pp. 1049-1062.

Nonlinearities and asymmetric adjustment

Bauer, M. (2015), "Inflation expectations and the news", International Journal of Central Banking, Vol. 39, pp. 1-40.

Bauer, M.D. and McCarthy, E. (2015), "Can we rely on market-based inflation forecasts?", FRBSF Economic Letter, Vol. 30, pp. 1-5.

Baum, C.F., Barkoulas, J.T. and Caglayan, M. (2001), "Nonlinear adjustment to purchasing power parity in the post-Bretton Woods era", Journal of International Money and Finance, Vol. 20 No. 3, pp. 379-399.

Bordo, M.D. and Siklos, P.L. (2015), "Central bank credibility: an historical and quantitative exploration", No. w20824, National Bureau of Economic Research.

Broock, W.A., Scheinkman, J.A., Dechert, W.D. and LeBaron, B. (1996), “A test for independence based on the correlation dimension", Econometric Reviews, Vol. 15 No. 3, pp. 197-235.

Ca'Zorzi, M., Muck, J. and Rubaszek, M. (2016), "Real exchange rate forecasting and PPP: this time the random walk loses", Open Economies Review, Vol. 27 No. 3, pp. 585-609.

Cheung, Y.W. and Lai, K.S. (1994), "Mean reversion in real exchange rates", Economics Letters, Vol. 46 No. 3, pp. 251-256.

Chortareas, G. and Kapetanios, G. (2009), "Getting PPP right: identifying mean-reverting real exchange rates in panels", Journal of Banking and Finance, Vol. 33 No. 2, pp. 390-404.

Chortareas, G.E., Kapetanios, G. and Shin, Y. (2002), "Nonlinear mean reversion in real exchange rates", Economics Letters, Vol. 77 No. 3, pp. 411-417.

Christopoulos, D.K. and León-Ledesma, M.A. (2010), "Smooth breaks and non-linear mean reversion: post-Bretton Woods real exchange rates", Journal of International Money and Finance, Vol. 29 No. 6, pp. 1076-1093.

Clarida, R. and Gali, J. (1994), "Sources of real exchange-rate fluctuations: how important are nominal shocks?", in Carnegie-Rochester Conference Series on Public Policy, North-Holland, Vol. 41, pp. 1-56.

Clarida, R.H. and Waldman, D. (2008), "Is bad news about inflation good news for the exchange rate? And, if so, can that tell us anything about the conduct of monetary policy?", in Asset Prices and Monetary Policy, University of Chicago Press, pp. 371-396.

Clark, T.E. and West, K.D. (2007), "Approximately normal tests for equal predictive accuracy in nested models", Journal of Econometrics, Vol. 138 No. 1, pp. 291-311.

Coakley, J. and Fuertes, A.M. (1997), "New panel unit root tests of PPP", Economics Letters, Vol. 57 No. 1, pp. 17-22.

Ding, H. and Kim, J. (2012), "Does inflation targeting matter for PPP? An empirical investigation", Applied Economics Letters, Vol. 19 No. 18, pp. 1777-1780.

Dodge, D. (2002), "Inflation targeting in Canada: experience and lessons", The North American Journal of Economics and Finance, Vol. 13 No. 2, pp. 113-124.

Dominguez, K.M. (1998), "Central bank intervention and exchange rate volatility”, Journal of International Money and Finance, Vol. 17 No. 1, pp. 161-190.

Feenstra, R.C. and Kendall, J.D. (1997), "Pass-through of exchange rates and purchasing power parity", Journal of International Economics, Vol. 43 Nos 1-2, pp. 237-261. 
JES

49,6

958

Frankel, J.A. and Rose, A.K. (1996), "A panel project on purchasing power parity: mean reversion within and between countries", Journal of International Economics, Vol. 40 Nos 1-2, pp. 209-224.

Froot, K.A. and Rogoff, K. (1995), "Perspectives on PPP and long-run real exchange rates", Handbook of International Economics, Vol. 3, pp. 1647-1688.

Ghodsi, S.H. (2017), Nonlinear ARDL Approach and the Housing Market in the US, University of Wisconsin-Milwaukee Press, Milwaukee.

Goh, S.K., Sam, C.Y. and McNown, R. (2017), "Re-examining foreign direct investment, exports, and economic growth in asian economies using a bootstrap ARDL test for cointegration", Journal of Asian Economics, Vol. 51, pp. 12-22.

Holmes, M.J. and Wang, P. (2006), "Asymmetric adjustment towards long-run PPP: some new evidence for Asian economies”, International Economic Journal, Vol. 20 No. 2, pp. 161-177.

Ince, O. (2014), "Forecasting exchange rates out-of-sample with panel methods and real-time data", Journal of International Money and Finance, Vol. 43, pp. 1-18.

Johansen, S. and Juselius, K. (1990), "Maximum likelihood estimation and inference on cointegrationwith applications to the demand for money", Oxford Bulletin of Economics and Statistics, Vol. 52 No. 2, pp. 169-210.

Kamada, K. and Nakajima, J. (2014), "On the reliability of Japanese inflation expectations using purchasing power parity”, Economic Analysis and Policy, Vol. 44 No. 3, pp. 259-265.

Kapetanios, G., Shin, Y. and Snell, A. (2003), "Testing for a unit root in the nonlinear STAR framework", Journal of Econometrics, Vol. 112 No. 2, pp. 359-379.

Kim, J. (2014), "Inflation targeting and real exchange rates: a bias correction approach", Economics Letters, Vol. 125 No. 2, pp. 253-256.

King, C.P. (2012), "Half life of the real exchange rate: evidence from the nonlinear approach in emerging economies", Journal of Economics and Management, Vol. 8 No. 1, pp. 1-23.

Kutan, A.M. and Dibooglu, S. (1998), "Sources of real and nominal exchange rate fluctuations in transition economies", Working Paper No. 1998-022, Federal Reserve Bank of St. Louis Working Paper Series.

Lavesson, N. (2011), Is Inflation Mean-Reverting?, Department of Economics, Lund University.

Lee, J. and Chinn, M.D. (1998), "The current account and the real exchange rate: a structural VAR analysis of major currencies", Working Paper No. w6495, National Bureau of Economic Research.

Lothian, J.R. and Taylor, M.P. (1996), "Real exchange rate behavior: the recent float from the perspective of the past two centuries", Journal of Political Economy, Vol. 104 No. 3, pp. 488-509.

McNown, R., Sam, C.Y. and Goh, S.K. (2018), "Bootstrapping the autoregressive distributed lag test for cointegration”, Applied Economics, Vol. 50 No. 13, pp. 1509-1521.

Molodtsova, T. and Papell, D.H. (2009), "Out-of-sample exchange rate predictability with Taylor rule fundamentals", Journal of International Economics, Vol. 77 No. 2, pp. 167-180.

Murray, C.J. and Papell, D.H. (2005), "The purchasing power parity puzzle is worse than you think", Empirical Economics, Vol. 30 No. 3, pp. 783-790.

Nkoro, E. and Uko, A.K. (2016), "Autoregressive Distributed Lag (ARDL) cointegration technique: application and interpretation", Journal of Statistical and Econometric Methods, Vol. 5 No. 4, pp. 63-91.

Norman, S. (2010), "How well does nonlinear mean reversion solve the PPP puzzle?", Journal of International Money and Finance, Vol. 29 No. 5, pp. 919-937.

Papell, D.H. (1997), "Searching for stationarity: purchasing power parity under the current float", Journal of International Economics, Vol. 43 Nos 3-4, pp. 313-332.

Pesaran, M.H. and Shin, Y. (1998), "An autoregressive distributed-lag modelling approach to cointegration analysis", Econometric Society Monographs, Vol. 31, pp. 371-413. 
Pesaran, M.H., Shin, Y. and Smith, R.J. (2001), "Bounds testing approaches to the analysis of level relationships", Journal of Applied Econometrics, Vol. 16 No. 3, pp. 289-326.

Ranchhod, S. (2003), "The relationship between inflation expectations survey data and inflation", The Reserve Bank of New Zealand Bulletin, Vol. 66 No. 4, p. 50.

Rogoff, K. (1996), “The purchasing power parity puzzle”, Journal of Economic Literature, Vol. 34 No. 2, pp. 647-668.

Sack, B. (2000), "Deriving inflation expectations from nominal and inflation-indexed Treasury yields", The Journal of Fixed Income, Vol. 10 No. 2, pp. 6-17.

Schmidt, P. and Phillips, P.C. (1992), "LM tests for a unit root in the presence of deterministic trends", Oxford Bulletin of Economics and Statistics, Vol. 54 No. 3, pp. 257-287.

Shin, Y., Yu, B. and Greenwood-Nimmo, M. (2014), "Modelling asymmetric cointegration and dynamic multipliers in a nonlinear ARDL framework", in Festschrift in Honor of Peter Schmidt, Springer, New York, NY, pp. 281-314.

Skare, M., Tomić, D. and Porada-Rochoń, M. (2019), "Testing nonlinear dynamics in terms of trade with aggregated data: implications for economic growth models", Engineering Economics, Vol. 30 No. 3, pp. 316-325.

Sollis, R., Leybourne, S. and Newbold, P. (2002), "Tests for symmetric and asymmetric nonlinear mean reversion in real exchange rates", Journal of Money, Credit and Banking, Vol. 34 No. 3, Part 1, pp. 686-700.

Sousa, R. and Yetman, J. (2016), "Inflation expectations and monetary policy", BIS Paper, (89d).

Stockman, A.C. (1987), "The equilibrium approach to exchange rates", FRB Richmond Economic Review, Vol. 73 No. 2, pp. 12-30.

Taylor, J.B. (2001), "The role of the exchange rate in monetary-policy rules", American Economic Review, Vol. 91 No. 2, pp. 263-267.

Taylor, M.P. (2006), "Real exchange rates and purchasing power parity: mean-reversion in economic thought”, Applied Financial Economics, Vol. 16 Nos 1-2, pp. 1-17.

Taylor, M.P., Peel, D.A. and Sarno, L. (2001), "Nonlinear mean-reversion in real exchange rates: toward a solution to the purchasing power parity puzzles", International Economic Review, Vol. 42 No. 4, pp. 1015-1042.

Wu, Y. (1996), "Are real exchange rates nonstationary? Evidence from a panel-data test", Journal of Money, Credit and Banking, Vol. 28 No. 1, pp. 54-63.

\section{Corresponding author}

Guglielmo Maria Caporale can be contacted at: Guglielmo-Maria.Caporale@brunel.ac.uk
Nonlinearities and asymmetric adjustment 